\title{
Environmental Impacts of Reflective Materials: Is High Albedo a 'Silver Bullet' for Mitigating Urban Heat Island?
}

Jiachuan Yang, Zhi-Hua Wang*, Kamil E. Kaloush

School of Sustainable Engineering and the Built Environment, Arizona State University, Tempe, AZ 85287, USA

\footnotetext{
* Corresponding author. Email: zhwang@asu.edu; Tel: 1-480-727-2933; Fax: 1-480-965-0577
} 


\section{Abstract}

Studies on urban heat island (UHI) have been more than a century after the phenomenon was first discovered in the early 1800s. UHI emerges as the source of many urban environmental problems and exacerbates the living environment in cities. Under the challenges of increasing urbanization and future climate changes, there is a pressing need for sustainable adaptation/mitigation strategies for UHI effects, one popular option being the use of reflective materials. While it is introduced as one effective method to reduce temperature and energy consumption in cities, its impacts on multi-dimensional environmental sustainability and large-scale non-local effect are inadequately explored. This paper provides a synthetic overview of potential environmental impacts of reflective materials at a variety of scales, ranging from energy load on a single building to regional hydroclimate. The review shows that mitigation potential of reflective materials depends on a portfolio of factors, including building characteristics, urban environment, meteorological and geographical conditions, to name a few. Precaution needs to be exercised by city planners and policy makers for large-scale deployment of reflective materials before their environmental impacts, especially on regional hydroclimates, are better understood. In general, it is recommended that optimal strategy for UHI needs to be determined on a city-by-city basis, rather than adopting a "one-solution-fits-all” strategy.

Keywords: Building Energy Efficiency; Cool Roofs; Reflective Materials; Regional Hydroclimate; Thermal Comfort; Urban Heat Island Mitigation; Urban Sustainability 


\section{Introduction}

The urban heat island (UHI) effect, higher temperatures in urban areas compared to surrounding rural areas, is a well-known phenomenon that has been documented in hundreds of cities worldwide [1,2]. UHI intensity scales with size and population density of cities, with an expanding city experiencing continuously degraded thermal comfort [3]. While a significant spatial and temporal variation is observed in the UHI intensity, many cities show a magnitude of 5-11 ${ }^{\circ} \mathrm{C}$ by mid-morning [4]. Elevated environmental temperatures in urban areas lead to rise of energy consumption for cooling [5-8], increase of peak electricity demand [9], degradation of air quality [10-13], and deterioration of thermal stress on residents [14,15]. In particular, UHI degrades the living environment and increases the risk of heat-related morbidity and mortality in cities especially if exacerbated by heat waves [15-17]; thus prevention of deaths under conditions of extreme high temperatures has become a significant public health concern [18]. Given the ever-increasing urban population and the potential for more frequent and/or more severe heat waves in the future [19], adaptation and mitigation strategies are critical to alleviate UHIs and their subsequent adverse environmental effects [20].

During the past decades, several strategies have been proposed, developed and implemented to mitigate UHI, including reflective materials $[21,22]$, materials with high optical and thermal performances [23,24], green roofs (also known as eco-roofs) [25-29], urban vegetation and shading [30,31], heat sinks [32,33], to name a few. Among these techniques, reflective materials have been extensively studied [34-36] and are considered as a promising method that has gained increasing acceptance as well as application in buildings [37,38]. As available free ground area in 
urban environment is limited, a substantial portion of research efforts on reflective materials has been devoted to reflective roofs [38,39], also known as white or cool roofs. In moderately insulated buildings, peak summer indoor temperatures may reduce by up to $2{ }^{\circ} \mathrm{C}$, and cooling loads may reduce by $10 \%$ to $40 \%$ after installation of reflective roofs, depending on climatic conditions and building characteristics [35]. At the global scale, implementation of reflective roofs and pavements over urban areas would induce a negative radiative forcing, which is equivalent to offsetting tens of billions tons of $\mathrm{CO}_{2}$ emission according to Akbari et al. [40,41]. Economic analyses show that manufacturing and life cycle costs of reflective materials are lower than those of conventional ones [42,43]. In the U.S., reflective roofs have been adopted as a requirement or credit in widely used building energy-efficiency standards since 1999 including ASHRAR 90.1, ASHRAE 90.2, the International Energy Conservation Code and California Title $24[38,44]$. The Department of Energy (DOE) launched a cool roof initiative in 2010 to facilitate reducing carbon emission and potentially slowing some possible precursors to climate change. Globally, reflective roofs begin to gain popularity in Europe, Asia and South America [37].

Though mitigation potentials of reflective materials are quite extensively investigated, synthetic studies of existing numerical and experimental researches on these materials and their potential environmental impacts at multiple scales are relatively limited. Santamouris et al. [36] summarized the development and assessment of cool materials in four phases for buildings and urban structures to mitigate UHI, with the main focus on materials and techniques per se. Later, Santamouris $[35,39]$ reviewed the status quo of different cool pavements as the mitigation strategy, and the cooling potentials of reflective roofs in comparison with green roofs. But these 
reviews are exclusively focused on the potential of temperature reduction and energy saving by reflective materials, while their impacts on other critical environmental aspects are barely discussed. Urban areas are hot spots that drive multi-sector environmental changes, consumption and production of resources within urban environment have local and regional implications for ecosystem services, hydroclimate, health and other factors [45]. Previous studies have indicated that large-scale deployment of reflective roofs in urban areas can lead to environmental impacts such as decreased precipitation [46,47] and/or improved air quality [48,49]. It is therefore imperative to evaluate, compare and summarize environmental impacts, at multiple scales and dimensions beyond the measure of environmental temperatures.

The objective of this paper is to provide a synthetic overview of potential environmental impacts as a result of implementation of reflective materials in cities. As the relevant literature has expanded enormously especially in the past decade, we restrict the scope of this review in a number of ways to avoid being overly lengthy. First, we only cover the literature published in English since 1990. Second, the review will focus on major environmental impacts of reflective materials, including temperature, energy consumption, hydroclimate, health risk, thermal comfort, and air quality. Technical development and manufacturing details have been reviewed in a previous study [39] and thus are not included here. Third, we constrain the scope to studies that were exclusively conducted on reflective materials. Studies addressing the combined effects of multiple mitigation strategies are excluded [30,50]. 


\section{Effect of reflective materials on environmental temperatures}

\subsection{Surface temperature}

The amount of solar radiation reflected from surface is determined by reflectivity of the materials. With higher solar reflectivity (albedo), reflective materials usually appear white in color and are able to absorb less radiation and maintain a lower surface temperature during daytime. This effect has been documented in a variety of previous studies, with most focused on summer time. Table 1 and 2 summarize the main characteristics and results from numerical simulations and field experiments, respectively. Although possible thermal benefits are readily available from existing studies, intercomparing the results is not a straightforward task, due to the variety in research methodology, performance standards, and implementation practices carried out by different researchers. Numerical simulations were run at a variety of scales, with vastly different regional characteristics and model setups, while experimental studies were conducted using various materials and techniques under different meteorological conditions.

It can be seen from Tables 1 and 2 that increasing reflectivity facilitates reduction of daytime surface temperature. And the magnitude of the reduction increases with the increment of reflectivity, when other conditions remain the same. Compared to summertime, temperature reductions in other seasons are expected to be smaller in magnitude, as solar radiation intensity reduces. However, only a few studies have reported seasonal variation of the impact $[51,52]$. During nighttime, albedo of materials becomes ineffective due to the absence of solar radiation. However, as more radiation is reflected during the day, less heat is stored in reflective materials compared to conventional ones. This can lead to small reductions of nighttime surface 
temperature, if not negligible [21,53]. In addition to meteorological conditions, temperature reductions also depend on geographical conditions. Reflective materials cool the surface by modifying the radiative energy impinged on land surfaces. Under strongly windy conditions, the advective effect can dominate the surface temperature variation. A field study in Athens found that reflective pavements could reduce surface temperature in an urban park up to $7.6{ }^{\circ} \mathrm{C}$ under non-shaded condition [54]; on the contrary, temperature reduction by reflective pavement is nearly negligible at the site close to the sea due to the advective effect of sea-land breeze.

The capability of reflective materials to mitigate UHIs depends on its ability to reflect more solar radiation, hence preventing the transfer of thermal energy into and through solid subsurface stratums. However, larger reflected radiation can be absorbed by surrounding surfaces and subsequently increases their temperatures. Levinson [55] found that increasing the ground albedo could heat or cool a near-ground object, depending on the object's albedo. When the object has an albedo of 0.3 , increasing ground albedo by 0.25 perturbs the environmental temperature by -1.1 to $0.3{ }^{\circ} \mathrm{C}$ for a human, -0.4 to $0.9{ }^{\circ} \mathrm{C}$ for a car, and 1.0 to $2.3{ }^{\circ} \mathrm{C}$ for a bungalow near ground. Reflective pavements will cool the object only if the object's albedo exceeds a critical value. An experimental study by Li [56] showed that temperature of building walls would be heated up by reflected energy from pavement surfaces, which could be 2 to $5{ }^{\circ} \mathrm{C}$ around noon. Compared to asphalt pavements, concrete pavements have higher albedo and consequently lead to a higher wall temperature. Temperature on the lower and middle parts of the wall is higher than that on other parts, mainly owing to the view factor. Additionally, Brender and Lindsey [57] conducted experiments in Las Vegas and observed hotter interior temperature $\left(5{ }^{\circ} \mathrm{C}\right.$ at maximum) in the 
conduit over a white roof as compared to dark-colored roofs. These findings imply that thermal interactions between pavements and nearby objects need special attentions when reflective materials are to be used. The interaction may not be a big risk in open areas, but it tends to be more serious in high-density urban centers where walls are close to pavements and thus subjected to more heating potentials by the reflected solar radiation from the adjacent pavements. It is expected that thermal interaction depends on various factors, such as pavement size, distance between walls and pavements, and thermal properties of walls and pavements. The lack of synthetic study on the building-pavement-atmosphere interactions at fine scales (building to neighborhood) calls for future studies along this line.

\subsection{Air temperature}

Unlike studies on surface temperature, research on air temperature mostly adopts numerical modeling approaches, with only a few employing experimental methods. Table 3 summarizes the existing studies that cover the impact of reflective materials on air temperature, including indoor air temperature in non-air-conditioned buildings and outdoor air temperature. Overall, cooling potentials of reflective materials on air temperature are notably smaller than those on surface temperature. Compared to results on surface temperature by reflective materials from numerical simulations and field experiments, results on outdoor air temperature are less consistent. Some studies reported a considerable reduction of atmospheric temperature by reflective materials to several degrees [21,48,58], while others concluded the reduction is small or negligible [59-62]. Moreover, a study by Jacobson and Ten Hoeve [63] found that increasing worldwide roof albedo 
would lead to local cooling but global warming, though highly uncertain, resulting from the magnified feedbacks at high latitudes over snow and sea ice. One main reason for the diversity in results is the turbulent mixing of mass and thermal energy in the lower atmosphere. Though surface temperatures have significant influence on air temperatures, their relationship is not constant in the urban environment due to the mixing process. Georgakis and Santamouris [64] carried out field experiments in a deep canyon in Athens during summer and found that turbulent mixing and horizontal advection inside the canyon homogenize the air temperature such that the impact of surface temperature on air temperature is relatively insignificant. Another important reason is the drastic variability of air temperature in vertical direction. Air temperature and its gradient are much higher near the ground than those at $2 \mathrm{~m}$, gradually decreasing as the distance from pavement surface increases [56]. Impact of reflective materials on air temperature is therefore different at various heights; consequently it is not surprising that a consensus is hard to reach without a "standardized" procedure of atmospheric temperature profile measurements. Simulations in Tokyo found that white roofs installed on medium- and high-rise buildings were ineffective in reducing ambient temperature at street level [65]. Reflective pavements, on the other hand, could reduce mean air temperature by about $0.1 \mathrm{~K}$.

With respect to indoor air temperature in non-air-conditioned buildings, existing studies agree well among one another in that a reduction of $1-3{ }^{\circ} \mathrm{C}$ can be achieved by the installation of cool roofs. Compared to outdoor air temperature, indoor air temperature is more important as the habitants are exposed to the latter most of the time during hot periods. Without air conditioning, indoor air temperature can exceed $30{ }^{\circ} \mathrm{C}$ for more than $85 \%$ of the time during heat waves [66]. 
As global climate change increases the frequency and length of heat waves, peak temperatures and duration of the hot spells will be aggravated in non-air-conditioned indoor environments. Though air conditioning is the most effective method to cope with extreme heat [67], lower socioeconomic and ethnic minority groups have less access to it that they are more vulnerable to heat stress $[16,68]$. Under such circumstance, reflective roofs serve as a convenient strategy to reduce indoor air temperatures and consequently reduce the health risks on residents.

\subsection{Urban heat island intensity}

The uppermost objective of application of reflective materials is to mitigate urban heat islands. Though researches on UHIs have lasted for more than a century, the intensity of a UHI is not yet rigorously defined [69]. Instead, a number of ad-hoc definitions of UHI intensity were used in the literature by different researchers under different conditions; one commonly used definition being the spatially-averaged temperature difference between an urban and its surrounding rural areas [70,71]. Whereas depending on the actual environmental temperature used (e.g. surface vs. atmospheric temperature, or radiant vs. sheltered temperature), UHI intensity can be sub-categorized, such as atmospheric, surface, or subsurface ones, the latter two being much less investigated [72]. As nonlinearity presents in the relationship between surface and air temperatures, it is anticipated that the resulted UHI intensities defined by different measures show different trends. Table 4 summarizes the observed UHI intensities of major cities in the world. It is clear from the table that UHI intensity varies vastly from city to city, due to the combined effect of various contributors, including population, geographical condition, climate 
condition, city geometry, etc. It is hard to directly compare the magnitude of UHI intensity of different cities, as in-situ measurements are carried out at different time in different seasons with different techniques. Generally speaking, UHI intensity tends to decrease with wind speed and cloud cover, and increase with city size and population. A thorough review on UHI research can be found in [85].

Usually intensity derived from surface temperature is considerably larger than that from air temperature. Kim and Baik [70] reported that annual average maximum UHI intensity was about $2.2{ }^{\circ} \mathrm{C}$ in Seoul from Mar 2001 to Feb 2002 based on air temperature from weather station data. UHI intensity was found to be stronger in nighttime than in daytime for Seoul, and tended to be weak in summer compared to other seasons. However, mean daytime UHI intensity in Seoul was found to be $8{ }^{\circ} \mathrm{C}$ in August 2001 based on surface temperature from satellite data [2]. Miao et al. [73] observed a UHI intensity of $0.05{ }^{\circ} \mathrm{C}$ for Beijing at 1000 LST based on air temperature, while analysis of remotely sensed surface temperature at 1030 LST showed an intensity of $10{ }^{\circ} \mathrm{C}$ [2]. The large gap was also found in modelling studies. Using a mesoscale numerical model, Hafner and Kidder [86] reported a UHI intensity of $1.2{ }^{\circ} \mathrm{C}$ based on surface temperature and the intensity was only $0.6{ }^{\circ} \mathrm{C}$ based on air temperature in Atlanta at 6 am on February 7, 1988. This diversity in definition of UHI intensity adds difficulty to comparing and evaluating potential and effectiveness of reflective materials as a UHI mitigation strategy.

Despite the difference in definition, UHI intensity derived from both temperatures has a strong diurnal variation. A couple of studies have reported that UHI intensities are larger during night time than in day time [11, 87-89], primarily due to the energy stored by large heat capacity 
of pavement surfaces. On the contrary, functioning with the presence of solar radiation, reflective materials are more effective during daytime. This phase lag raises concerns about the effectiveness of reflective materials in mitigating UHIs during nocturnal cycle. In addition, Ryu and Baik [90] identified that heat radiating from vertical surfaces has a great impact on nighttime UHI intensity. In order to alleviate this effect, reflective materials applied on building walls are preferred to that on the street level.

It is also noteworthy that an important physical process is largely neglected in existing studies. If applied at a large scale, reflective pavements stabilize local air and modify regional air flow patterns when they reduce urban surface temperature. This modification of atmospheric boundary layer dynamics over a built terrain imposes temperature changes on surrounding rural areas, which is not adequately investigated hitherto. Millstein and Menon [91] found that by increasing roof albedo of 0.25 and pavement albedo of 0.15 in urban areas over the continental U.S., summertime afternoon temperature could be decreased by up to $0.53{ }^{\circ} \mathrm{C}$ in urban locations. For rural areas, some locations experience a temperature reduction while others has an increment of up to $0.27{ }^{\circ} \mathrm{C}$. This apparent increase in surrounding rural temperatures is an unintended consequence, which needs to be carefully examined in determining the actual mitigation potential of reflective materials.

\section{Impact of reflective materials on building energy consumption}

During the past century, global population has become increasingly urbanized and turned cities into large energy consumers. One substantial adverse consequence of UHIs is the increase 
of building energy consumption. In the U.S., buildings consume $39 \%$ of energy and $68 \%$ of its electricity, of which $97 \%$ is consumed on operation [92]. Building energy consumption in cities is closely related to environmental temperatures, where increased UHI intensity and heat wave events due to land use land cover modification and changes in global and regional climatic patterns inevitably lead to increase in energy demand. Akbari et al. [93] reported that for U.S. cities with population larger than 100000 , peak electricity load will increase by $1.5-2 \%$ for every $1{ }^{\circ} \mathrm{F}$ increase in ambient temperature. In Hong Kong, it was found that electricity consumption would increase by $9.2 \%, 3.0 \%$ and $2.4 \%$ in domestic, commercial and industrial sectors, respectively, for $1{ }^{\circ} \mathrm{C}$ increase in ambient temperature [5]. UHI in the central Athens reduce heating load by up to $30-55 \%$ in winter [94]. However, cooling load in summers is almost doubled, significantly outweighing the reduction in winter. With its influence on temperature, reflective materials are capable to reduce cooling loads of buildings during hot periods, especially early afternoons during the summer. On the other hand, reflective materials can increase heating loads during cold periods, known as the "heating penalty" of high albedo [95-97].

Numerous studies have addressed the impact of reflective materials on energy consumption in urban areas. Results are summarized in Table 5. Most of the studies have been focused on the impact of reflective roofs, while only a few have accessed the effect of reflective pavements. Both cooling savings and heating penalties are reported, with their relative magnitude varying with building types, geographical and meteorological conditions. At the annual scale, most of existing studies that have evaluated the net impact favor a reduction in energy consumption by 
reflective roofs. Using the DOE-2 building energy simulation program, Akbari et al. [95] investigated impacts of reflective roofs in eleven U.S. metropolitan statistical areas. Largest savings in individual buildings were found in cities under the hottest and sunniest climate. Savings decreased as the climate got cooler, but net savings were still positive for most building types in cities as far north as Chicago. Akbari and Konopacki [96] accessed the influences of cool roofs on three building types with various characteristics over 240 locations across the U.S.. It was found that only in electric heating residential buildings under climates with less than 1000 cooling-degree-days, increasing roof albedo from 0.2 to 0.5 would lead to larger heating penalty than cooling saving. Levinson and Akbari [97] combined building energy simulations, local energy prices, local electricity emission factors, and local estimates of building densities to characterize local per-CRA (conditioned roof area) and per-LA (land area) annual rates of energy cost savings in 236 cities across the U.S. after installation of a cool roof. Using the DOE-2.1E building energy model with a roof assembly heat transfer module, they predicted that a cool roof almost always reduced the annual cooling load more than it increased the annual heating load per-CRA, with the greatest saving in Hawaii and the least in Alaska. With TRNSYS thermal simulation software, Synnefa et al. [98] found that application of cool roofs lead to a larger cooling load reduction (9 to $48 \mathrm{kWh} / \mathrm{m}^{2} /$ year) than heating penalty $\left(0.2\right.$ to $17 \mathrm{kWh} / \mathrm{m}^{2} /$ year) for 27 cities (latitude from $19.19^{\circ}$ to $43.4^{\circ}$ ) around the world. Daily peak electricity demands were also found to decrease substantially in these studies. Against energy savings, a later simulation by Oleson et al. [99] showed that reflective roofs increased winter interior heating more than they decreased summer air conditioning with respect to the global annual average. 
While reflective roofs reduce cooling loads by reducing the transfer of heat into buildings from roofs, the same is not necessarily true with regards to pavements at the ground level. Heat transport of road pavements is often influenced by the adjacent thermal environment through surface-atmosphere interactions in, e.g. a street canyon. Yaghoobian et al. [100] applied a three-dimensional heat transfer model (TUF3D) and found a substantial reduction in short-wave radiative transfer from ground to building by using low albedo ground surfaces, rather than reflective pavements. This reduction leads to a consequent savings in the daily design cooling load of nearby buildings by 17\%. Later Yaghoobian and Kleissl [60] adopted a three-dimensional building-to-canopy model (TUF-IOBES) to investigate the effects of reflective pavements on building energy usage. Focusing on thermal interactions between buildings and surrounding microclimate in the urban canyon, the study found that increasing ground solar reflectivity from 0.1 to 0.5 near a four-story office building $\left(1820 \mathrm{~m}^{2}\right.$ floor area, $47 \%$ window-to-wall ratio) in Phoenix would increase annual cooling loads up to $11 \%(33.1 \mathrm{kWh} / \mathrm{m} 2)$. Annual heating load was not sensitive to ground surface albedo modification. These results illustrate the potential of increased cooling loads in adjacent buildings by reflected solar radiation from high albedo reflective pavements.

With respect to studies on energy consumptions, two issues are worth mentioning. First, among the existing experimental studies, energy consumption data is mostly available in summers. Building energy simulation models are calibrated for this period and then used to estimate energy consumption at the annual scale. Such treatment may lead to bias in predicting heating loads in winter and consequently errors in estimating overall energy consumption. To 
accurately evaluate the net energy savings by reflective materials, collection of data during entire annual cycles is recommended. Second, the impact of urban environment at larger scales is often neglected. Existing studies mostly estimate energy consumptions of cities based on building-scale models or temperature-dependent functions, where geometric and geographical complexities at city scales, e.g. spatial heterogeneity, orographic effect, variability in building geometry and density, etc. are not properly represented. For example, Yaghoobian and Kleissl [60] adopted a 3D model and reported that annual thermal loads of buildings decreased with canopy height-to-width ratio. Other variables such as canyon orientation can also have implications for urban energy consumption as it affects radiation budget and wind speed.

Incorporation of environmental complexity of built terrains into calculation of energy consumption is therefore important for future numerical simulations in order to provide guidance to building energy efficiency design and city planning. To do this, one group of models having particularly promising potential is the urban land surface modeling schemes, the so-called urban canopy models (UCMs) developed in the widely-used Weather Research and Forecasting (WRF) platform [101,102] by the National Center for Atmospheric Research (NCAR). The most common urban land surface models in WRF are the single layer [103-107] and the multi-layer UCMs [108-111]. WRF-UCM system integrates the physics of energy and mass transport in the urban canopy layers and the mesoscale atmospheric dynamics, thus provides a versatile modeling framework for multi-scale numerical simulations ranging from building to regional scales. Detailed physically-based building energy model has been implemented in the multi-layer UCM $[110,111,8]$ and outperforms the commonly used EnergyPlus ${ }^{\mathrm{TM}}$ model [112, 113]. A 
detailed report on synthetic analysis of UCM schemes can be found in Grimmond et al. [114, $115]$.

\section{Environmental impact at large: city and regional hydroclimates}

By increasing albedo, reflective materials reduce available energy at the surface and weaken turbulent heat fluxes. Simulation by Scherba et al. [116] showed that peak sensible heat flux could reduce by about 70\% after replacing a black roof with a white roof during the summer, and total daily sensible heat flux was decreased by approximately $80 \%$. Turbulent fluxes arising from the Earth's surface are responsible for changes in the atmospheric state variables. With that, significant reduction in sensible fluxes indicates a possible strong impact of reflective materials on local and regional hydroclimate. This implication has not raised concerns of the public until recently that adverse effects are reported in several simulation studies.

Millstein and Menon [78] were the first to bring up this issue. They employed the WRF model to investigate the impact of large-scale cool roof deployment. Assuming a 0.25 and 0.15 increase in albedo of roofs and pavements in urban areas with adoption of reflective materials across the U.S., results showed that summertime afternoon temperature could be increased by up to $0.27{ }^{\circ} \mathrm{C}$ in some rural locations. These locations were associated with fewer or thinner cloud cover, lower soil moisture and less precipitation. Later, Bala and Nag [117] adopted the NCAR Community Atmospheric Model (CAM) version 3.1 with a slab ocean/thermodynamic sea ice model to access the potential for mitigation of climate change by enhancing the albedo over land. Instead of modifying the surface albedo, they increased the planetary albedo of clouds over land 
by $1.9 \%$ as an idealized case. It was shown that albedo enhancement caused a large residual sinking motion over land, leading to a significant decrease of $13.3 \%$ and $22.3 \%$ in global land-mean precipitation and runoff, respectively. Note that the numbers are not realistic due to the use of an idealized case, however, their results suggest the likelihood of large adverse regional impacts on the hydroclimate. More recently, Georgescu et al. [46] applied WRF to investigate the alleviation potential of highly reflective roofs on UHI-induced warming in Sun Corridor. Results showed that under maximum urban expansion scenario, implementation of reflective roofs reduced evapotranspiration throughout the calendar year, especially in summer. Total accumulated precipitation was decreased by $4 \%$, further worsening water resources conditions in the semi-arid area. On the continental scale, Georgescu et al. [47] found that reflective roof deployment over expanded urban areas reduced summertime precipitation by 2-4 $\mathrm{mm} /$ day along a corridor extending from Florida to the northeastern United States, and reduced monsoon precipitation considerably in southwestern United States. Reduction during other seasons was smaller compared to summer.

These studies show qualitative agreement that large-scale albedo enhancement over land leads to reduced precipitation. Reduced precipitation is expected to have consequences on the already stressed water demand for households, agriculture, power generation, and aquatic ecosystem, especially in the arid and semi-arid regions. Given the rising global water stress due to climate change and population growth [118], measures for such consequences are essential before large scale implementation of reflective materials. With regard to numerical simulations, the use of integrated multi-scale models such as WRF to quantify the large scale environmental 
impact of reflective materials is still at its infancy, and its future employment by modelers is strongly encouraged.

\section{Thermal comfort and health risk consideration}

In cities, people experience intense thermal discomfort during hot days in outdoor or non-air-conditioned indoor environments. With its ability to reduce surface and air temperature, reflective materials undoubtedly modify the thermal comfort in a built environment. Human thermal comfort is a rather subjective measure that is related to relevant environmental, physiological and other aspects that affect the comfort level of human bodies. Environmental factors that contribute to human thermal comfort include environmental temperature (though quite vaguely defined), humidity, wind speed, radiative exposure, ambient evaporative and sensible fluxes, etc.; a latest survey on this topic can be found in [15]. The use of reflective materials mainly modifies the environmental temperature and radiative exposure, which in turn lead to the change of thermal comfort level. In non-air-conditioned indoor environment, reflective roofs reduce indoor temperature by reflecting solar radiation and preventing the transfer of heat into the buildings. Synnefa et al. [98] evaluated the effect of reflective roofs in 27 cities around the world with TRNSYS thermal simulation software. They assessed the impact on indoor thermal comfort by using threshold temperature from the ASHRAE standard 55 [119]. Results showed that increasing roof albedo by 0.4 could reduce hours of discomfort by as much as $75 \%$ during the summer for a threshold value of $27^{\circ} \mathrm{C}$. For a threshold temperature of $29{ }^{\circ} \mathrm{C}$, reductions in hours of discomfort are 5\%-97\% and 9\%-100\% when albedo is increased by 0.4 
and 0.65 , respectively. Using the same software, study of a cool roof application on a $700 \mathrm{~m}^{2}$ roof in Sicily found that hours with temperature exceeding $27{ }^{\circ} \mathrm{C}$ could reduce by up to more than $40 \%$ in studied rooms under non-insulated conditions [54]. After accounting for building insulations, the reduction was about $20 \%$. Enhanced indoor thermal comfort by reflective roofs is also reported in Barcelona, Palermo, and Cairo [120].

In outdoor environments, quantifying thermal comfort is much more complicated due to the variety of surrounding environment. To access the comfort condition, a large number of indices have been developed, such as Human Thermal Comfort Index (HTCI) [68], Cooling Power (CP) comfort index [121], Discomfort Index (DI) [14], Index of Thermal Stress (ITS) [122], and Physiological Equivalent Temperature (PET) [123]. These indices account for different environmental factors with different weight in their definitions, thus the outcomes can be vastly different. For example, using the CP comfort index, a function of mean ambient temperature and wind speed, Santamouris et al. [54] found that applying reflective pavements over an urban park of $4500 \mathrm{~m}^{2}$ in the greater Athens area could significantly improve the comfort condition, from almost "extremely hot" to close to "quite hot" (note the subjective description). While using the Effective Surface Temperature index, a measure accounting for air temperature, aerodynamic resistance, radiation and shape factor, Lynn et al. [124] suggested that reflective pavements were an ineffective method for improving thermal comfort of pedestrians in New York. The reason was that reflective pavements increased reflected solar radiation more than they decreased the heat flux emitted from the ground. This finding is supported by later studies with various indices where reduced surface temperature was found not enough to offset increased radiation loads 
from reflective pavements $[56,125,126]$. As a result, if reflected radiation is considered, the net effect of increasing the pavement albedo can lead to an increase in the thermal stress to which pedestrians are exposed, rather than the expected improvement in thermal comfort.

When reflected radiation increases the thermal discomfort, it also poses additional health risks on pedestrians unsheltered. Solar radiation is the radiant energy within a broad region of the electromagnetic spectrum that includes ultraviolet (UV), visible (light) and infrared radiation (IR). When unspecified, albedo usually refers to average among the visible range. Studies have shown that light-colored materials can have similar or lower UV albedo compared to dark materials $[127,128]$. Furthermore, some reflective materials such as white clay can evidently increase the intensity of reflected UV radiation [129]. UV radiation is harmful to living cells and can result in sunburn, increased rate of aging of the skin, and skin cancer, with its damage accumulating over years [130]. Proper selection of reflective materials is therefore necessary to avoid the health risk [131]. Moreover, increasing the albedo of urban surfaces can potentially cause glare [132], which may disturb occupants of taller neighboring buildings when applied to roofs, and make pedestrians on nearby sidewalks suffer when applied to walls. Light-colored pavement on roads provides less lane demarcation due to the poor visibility of white lines, potentially increasing driving risks [133]. These effects have raised extensive concerns and efforts to develop reflective materials that absorb in visible part of spectrum but exhibit high reflection in the near infrared part [36]. Light pollution is another potential adverse effect of reflective materials. In natural environments, stray and obtrusive lights at night, regardless of their purpose, are generally referred to as light pollution. A recent study by the International 
Dark-Sky Association at the Brecon Beacons National Park found asphalt surfaces can reduce the upward light reflected by half when compared to concrete surfaces, regardless of luminaire light distribution [134]. Reflective pavements are expected to increase the upward reflected light, which is likely to result in less visibility of the night sky and stronger light pollution.

\section{Impact of reflective materials on air quality}

Air pollution has been a critical concern for urban environments for decades. As large energy consumers, cities are associated with large power plants and combustion of fossil fuels, which emerge as the main source of air pollutants [135]. UHI tend to degrade the air quality as heat accelerates the chemical reactions in the atmosphere [136]. Rosenfeld et al. [22] reported that probability of urban smog increased by $6 \%$ per ${ }^{\circ} \mathrm{C}$ when maximum daily temperature exceeds $22{ }^{\circ} \mathrm{C}$. By modulating environmental temperatures over built terrains, reflective materials have direct and indirect effects on urban air quality.

In terms of direct effects, reduced air temperature can slow the photochemical production of pollutants. Among the air pollutants, studies in urban areas have been focused on ozone, due to its strong oxidant property and potential damage to humans once the concentration is increased [137]. Using data from 23 experimental stations, Stathopoulou et al. [12] concluded that ambient air temperature is the predominant parameter in affecting the ozone concentration. Among the researchers, Taha is the one that has pioneered most of the studies in this field. In 1997, he employed the Colorado State University Mesoscale model (CSUMM) with the Urban Airshed Model (UAM) to assess the impacts of large-scale deployment of high-albedo materials on air 
quality in the South Coast Air Basin (SoCAB) in California during a late-August period [138]. When surface albedo was increased by 0.3 over the urban areas, peak concentration of ozone was decreased by up to $7 \%$ at 3pm and total ozone mass in the mixed layer reduced by up to $4.7 \%$. Later in 2008, he applied a urbanized mesoscale model uMM5 with the Comprehensive Air Quality Model with Extensions (CAMx) to evaluate the impacts of UHI mitigation strategies on air quality in southern and central California [48,139]. It was found that increasing pavement albedo in urban areas improved the air quality significantly. Daily 1-hour peak, daily maximum 8-hour average and daily average urban ozone concentration in southern California were decreased by 5, 3 and 2 ppb, respectively [139]. In Sacramento, increasing albedos of roof, wall and ground by $0.1,0.25$ and 0.08 would reduce ozone concentration by up to 16 -26 ppb during the summer [48]. Daily maximum 8-hour average can be decreased by 4-13\% across simulation days and monitor locations. Note that negative impacts on ozone concentration by increasing albedo were also observed in these studies; but the net effect over an entire urban area almost always leads to a reduction. In Sacramento, ozone concentration was increased by up to 9-11 ppb upwind of urban areas during certain hours [48]. The reason this occurs lies in the relative magnitudes of emission and chemistry $(E+C)$ versus those of vertical mixing and advection $(\mathrm{M}+\mathrm{A})$. Cooling of urban surfaces increases magnitudes of the former but reduces magnitudes of the latter. Effect of reflective materials therefore depends on balance of these two magnitudes, which varies from location to location. Taha [140] showed that there was a threshold beyond which further increase of albedo tended to produce smaller net improvement, due to the 
significant reduction of $\mathrm{M}+\mathrm{A}$. These findings are presented and discussed in a recent publication [49].

With respect to indirect effects, lower air temperature reduces energy consumption, which in turn reduces emissions of greenhouse gases and air pollutants from power generation. Rosenfeld et al. [141] estimated that reduced air temperature by reflective pavements in Los Angeles was equivalent to emission of $\mathrm{NO}_{\mathrm{x}} 175$ tons/day. Levinson and Akbari [97] used the DOE-2.1E building energy model to assess the potential benefits of cool roofs on commercial buildings in 236 cities across the U.S. In their study greenhouse gas and pollutant emission were determined by electrical and gas energy consumptions. Results showed that increasing roof albedo from 0.2 to 0.55 could offer $\mathrm{CO}_{2}$ reduction of $1.07-4.97 \mathrm{~kg} / \mathrm{m}^{2}, \mathrm{NO}_{\mathrm{x}}$ reduction of $1.70-11.7 \mathrm{~g} / \mathrm{m}^{2}, \mathrm{SO}_{2}$ reduction of $1.79-26.1 \mathrm{~g} / \mathrm{m}^{2}$, and Hg reduction of $1.08-105 \mu \mathrm{g} / \mathrm{m}^{2}$ annually in study cites. At the global scale, implementation of reflective materials in urban areas can decrease atmospheric temperature and offset warming effect from greenhouse gases. Lifetime benefit of the reflective materials is equivalent to emission reduction of tens to hundreds of billion tons of $\mathrm{CO}_{2}[40,41]$.

Another important environmental impact is the depression of planetary boundary layer (PBL) height caused by reduced vertical mixing from reflective materials. Sailor [142] found deployment of reflective pavements lead to a depression of about 50m in PBL height at the early afternoon (roughly 10\%) in Los Angeles, Riverside and Burbank. Lower height can increase the concentration of pollutants in the PBL and potentially affect the air quality in urban canopies. Due to the scarcity of multi-scale numerical modeling of urban areas, similar to the concern of albedo effect at large scale hydroclimate, the modification of PBL dynamics and 
thermodynamics over built terrains caused by reflective materials requires extensive future research effort.

\section{Discussion}

Environmental impacts of reflective materials at a variety of scales are reviewed in this report. Subject to different environmental conditions (climate, geography, morphology, and scale of study), these impacts reveal widely variable or even opposite trends, as reported in the literature. This lack of consistency is mainly due to the absence of standardized procedure for both experimental measurements and numerical models to accurately quantify the environmental impacts of reflective materials, which in turn imposes difficulty in prioritizing or even justifying their usage under certain conditions. Moreover, the complexity of built environments is largely underestimated in most existing studies of high albedo pavement materials. In particular, interactions between building physics and atmospheric dynamics at large scales are often neglected, e.g. "are there size effect associated with large scale implementation of reflective pavements and feedback mechanism between it and regional hydroclimate?” remains an open question. For sustainable development of future cities in adopting reflective pavements, extensive research effort is still imperatively needed. Some of the major players that needs to be addressed in future studies are discussed as follows.

(a) Scale effect. Effects of reflective material can change with the scale of its deployment. An illustration of the scale effect is shown in Figure 1. Intuitively, reflective materials applied on a single building will not exhibit same hydrothermal behavior as those on the entire city, and vice 
versa. Consider the limiting case: does perfect knowledge of the thermal characteristics of reflective materials on a single building (Figure 1c) necessarily allow us to quantify the effect of changing albedo of all roofs in a city (Figure 1a), by simply "summing up” numerical modeling results representing street canyons (Figure 1b)? For example, a study by Botham et al. [143] found that placement of a single white roof could enhance local vertical mixing, increased surface temperature on building walls by bringing warm air from other roofs to the street level. When white roofs were deployed on all buildings, this phenomenon disappeared that temperatures on all urban facets were decreased. In terms of hydroclimate, large-scale deployment of reflective roofs reduces vertical mixing significantly, leading to reduction in regional precipitation and cloud formation [46,47]. When reflective roofs are applied over a single building, this impact will not happen as the reduction of mixing is not strong enough to affect overall turbulent fluxes arising from the city. This apparent size effect necessitates the use of different experimental and numerical tools for characterizing and simulating reflective materials at different scales. Moreover, among the existing large-scale studies (i.e., city, continental, and global scale), it is usually assumed that reflective materials are installed over the entire urban areas, neglecting the spatial distribution inside the city. More practical scenarios need to be considered for future numerical modeling to overcome errors associated with this simplification.

(b) Geographical and meteorological conditions. Both positive and negative impacts of reflective materials depend on geographical and meteorological conditions, either at a building scale or at a city scale. Compared to areas near coasts, reflective roofs bring a much higher 
reduction in surface temperature to areas at inland [54]. Annual energy savings by reflective roofs are more significant in low-latitude cities than in high-latitude cities, under hot climates than under cool climates, and with clear skies than with cloudy skies $[97,120]$. Reduction of precipitation by reflective roofs is significant at east coast of the United States, but found to be negligible at west coast [47]. These results of pioneering studies indicate that magnitudes of actual environmental impacts of reflective pavements (either measurements or simulations) are usually site-dependent. There is unlikely a set of universally applicable results, measurements or simulations, that can be easily ported to provide guidance for urban design and planning in cities located in different geographic and climatic zones. Instead, detailed measurements and/or modeling of urban environment are not only necessary but essential in quantifying and prioritizing UHI mitigation strategies, for each city has its unique characteristics.

(c) Uncertainty and variability of models. Up to date, a large part of research findings and our knowledge on reflective materials is derived based simulation studies. It is important to bear in mind that significant variability exists in models' setup and assumptions, which implies that different models could yield quantitatively different results. Take thermal comfort for an example, without consideration of radiation effect, model predicts an improvement in outdoor thermal comfort of pedestrians by installation of reflective materials. After accounting for reflected radiation, model suggests a negative net impact on thermal comfort in outdoor urban environment. In addition, the driver of built environment simulations, viz. forcing from climate models also subjects to considerable uncertainties, to the extent that different global models can disagree on the future trend of climate changes expected in particular regions [144,145]. As part 
of the IPCC Fourth Assessment (IPCC AR4) experiment, the ability of 22 models to predict South Asian summer monsoon precipitation has been examined. While 19 out of 22 models are able to capture the maximum precipitation, predicted total rainfall varies from $500 \mathrm{~mm}$ to 900 $\mathrm{mm}[146]$.

Besides, the variability among modeling schemes, uncertainty within any individual model itself cannot be ignored. As field observation at global scale is currently unavailable, climate models are usually driven by reanalysis data, where marked variability has been reported [147,148]. Widely-used reanalysis datasets for climate monitoring and research include NCEP/NCAR Reanalysis I [149], NCEP-DOE Reanalysis II [150], NCEP Climate Forecast System Reanalysis [151], ERA 40 year Reanalysis [152], 20th Century Reanalysis [153], NASA Modern Era Reanalysis for Research and Application [154], etc. Realistic and reliable modeling of reflective materials and their environmental impacts, therefore require substantial efforts devoted for quantifying and reducing numerical errors associated with uncertainties through, e.g. ensemble simulations $[145,155,156]$.

(d) Alternative strategies for UHI mitigation. It is debatable that what the best UHI mitigation strategy is; the list of strong candidates include reflective pavements, green roofs, phase changing materials, permeable pavements, to name a few. Shahidan et al. [62] investigated the optimum cooling effect of UHI mitigation strategy in tropical climate. Results from ENVI-met simulations showed that tree quantities and their canopy density were paramount parameters for temperature reduction and energy savings. Increasing ground albedo to 0.8 had an insignificant impact under conditions with high density trees. Another study with GIS-based 
model CITYgreen also reported that reflective roofs appeared to be a less effective strategy in achieving energy savings on buildings more than one story in height in Newark and Camden compared to urban trees [157]. Compared to reflective roofs, green roofs have better performances in cold climates and in non-insulated buildings [158,159]. Under certain conditions, green roofs are more effective in reducing surface temperature [52], indoor air temperature [160], and annual building energy loads [161]. Even in terms of pavements, albedo is not the only determinant parameter that affects the thermal performances. Simpson and Mcpherson [162] found that with a lower emissivity and a higher albedo, temperature of silver roof was similar to that of brown roof. Emissivity determines the dissipation of energy stored in pavements that it plays a vital role in nocturnal temperatures [53]. Permeable pavements, pavements with high thermal capacity and conductivity have also been studied as strategies for UHI mitigation [39]. For a specific city, potential benefits of various solutions should be compared to come up with the optimum strategy for mitigating UHI.

\section{Conclusion}

While reflective material is becoming an increasingly popular option in our urban planning today for mitigating the UHI effect, its environmental impacts, especially those involving large scale urban-atmosphere interactions, are not clearly understood. In this review we compare and summarize recent research advances in the literature to provide a comprehensive overview of potential environmental impacts caused by implementing reflective materials to mitigate UHI. Though studies on this topic have expanded enormously, conclusions are mostly drawn from 
numerical simulations that we recognize the need of further research efforts for field measurements, especially in seasons other than summer.

With high albedo, reflective materials redirect more radiation and reduce surface temperatures, which in turn lead to lower air temperatures. However, reflected solar radiation can increase the temperature of the surrounding built environment and consequently increase its cooling load, such that overall benefits of reflective pavements and roofs can be less than expected. Reflected UV radiation, glare, and thermal discomfort are concomitant with the reflected radiation that attention is required to their impact on human health. In terms of energy consumption, reflective materials results in cooling savings and heating penalties, whose relative magnitude depending on complex interactions of many urban environmental factors, including building characteristics, urban morphology, geographical locations, local climate, etc. Reflective materials on different urban spatial locations can lead to opposite effects with regards to energy consumption. When applied at a large scale, reflective materials have positive impact on urban air quality directly and indirectly. However, resulted significant reduction in precipitation, runoff, and soil water content requires special attentions, especially in arid and semi-arid regions.

In summary, outcomes of existing experimental and modeling studies with high-albedo materials indicate thermal benefits of temperature reduction and energy savings. However, development of future generations of cities essentially embraces multiple dimensions of sustainability principles that multi-scale environmental, multi-sector socioeconomic elements, and regional impacts need to be accounted for [163]. Looking beyond the mitigation potentials for UHIs, city planners and policy makers should not only be aware of but set up standards in 
quantifying potential environmental impacts of reflective materials. With plenty alternatives and emerging new technologies, "the" optimal strategy for UHI mitigation and sustainable urban development in general, is likely to invoke a portfolio of different options varying from city to city, rather than relying on a "one-solution-fits-all" strategy. Neither high albedo materials nor any other individual technology, seem to be a silver bullet for mitigating UHI.

\section{Acknowledgement}

This paper is based upon work supported by the National Science Foundation under grant number CBET-1435881. Partial financial support provided by the National Asphalt Pavement Association and the National Center of Excellence for SMART Innovations at Arizona State University is gratefully acknowledged. 


\section{Reference}

[1] Santamouris M. Heat island research in Europe: the state of the art. Adv Build Energy Res. 2007;1:123-50.f

[2] Tran H, Uchihama D, Ochi S, Yasuoka Y. Assessment with satellite data of the urban heat island effects in Asian mega cities. Int J Appl Earth Observation Geoinf. 2006;8:34-48.

[3] Lee TW, Lee JY, Wang Z-H. Scaling of the urban heat island intensity using time-dependent energy balance. Urban Climate. 2012;2:16-24.

[4] Aniello C, Morgan K, Busbey A, Newland L. Mapping micro-urban heat islands using Landsat TM and a GIS. Comput Geosci. 1995;21:965-9.

[5] Fung W, Lam K, Hung W, Pang S, Lee Y. Impact of urban temperature on energy consumption of Hong Kong. Energy. 2006;31:2623-37.

[6] Kolokotroni M, Zhang Y, Watkins R. The London Heat Island and building cooling design. Solar Energy. 2007;81:102-10.

[7] Hirano Y, Fujita T. Evaluation of the impact of the urban heat island on residential and commercial energy consumption in Tokyo. Energy. 2012;37:371-83.

[8] Salamanca F, Georgescu M, Mahalov A, Moustaoui M, Wang M, Svoma BM. Assessing summertime urban air conditioning consumption in a semiarid environment. Environ Res Lett. 2013;8:034022.

[9] Hassid S, Santamouris M, Papanikolaou N, Linardi A, Klitsikas N, Georgakis C, et al. The effect of the Athens heat island on air conditioning load. Energy Build. 2000;32:131-41.

[10] Huizenga C, Abbaszadeh S, Zagreus L, Arens EA. Air quality and thermal comfort in office 
buildings: Results of a large indoor environmental quality survey. Center for the Built Environment. 2006.

[11] Sarrat C, Lemonsu A, Masson V, Guedalia D. Impact of urban heat island on regional atmospheric pollution. Atmos Environ. 2006;40:1743-58.

[12] Stathopoulou E, Mihalakakou G, Santamouris M, Bagiorgas HS. On the impact of temperature on tropospheric ozone concentration levels in urban environments. J Earth Syst Sci. 2008;117:227-36.

[13] Nazaroff WW. Exploring the consequences of climate change for indoor air quality. Environ Res Lett. 2013;8:015022.

[14] Pantavou K, Theoharatos G, Mavrakis A, Santamouris M. Evaluating thermal comfort conditions and health responses during an extremely hot summer in Athens. Build Environ. 2011;46:339-44.

[15] Mishra AK, Ramgopal M. Field studies on human thermal comfort — An overview. Build Environ. 2013;64:94-106.

[16] Patz JA, Campbell-Lendrum D, Holloway T, Foley JA. Impact of regional climate change on human health. Nature. 2005;438:310-7.

[17] Li D, Bou-Zeid E. Synergistic interactions between urban heat islands and heat waves: The impact in cities is larger than the sum of its parts. J Appl Meteorol Climatol. 2013;52:2051-64.

[18] Kovats RS, Hajat S. Heat stress and public health: a critical review. Annu Rev Public Health. 2008;29:41-55.

[19] IPCC. Managing the risks of extreme events and disasters to advance climate change 
adaptation. A special report of working groups I and II of the Intergovernmental Panel on Climate Change [Field CB, Barros V, Stocker TF, Qin D, Dokken DJ, Ebi KL, et al.]. Cambridge University Press, Cambridge, UK, and New York, NY, USA, 582 pp. 2012.

[20] USEPA. Reducing urban heat islands: Compendium of strategies.

http://www.epa.gov/heatisland/resources/compendium.htm. Retrieved July 3rd, 2008.

[21] Synnefa A, Dandou A, Santamouris M, Tombrou M, Soulakellis N. On the use of cool materials as a heat island mitigation strategy. J Appl Meteorol Climatol. 2008;47:2846-56.

[22] Rosenfeld AH, Akbari H, Bretz S, Fishman BL, Kurn DM, Sailor D, et al. Mitigation of urban heat islands: materials, utility programs, updates. Energy Build. 1995;22:255-65.

[23] Karlessi T, Santamouris M, Apostolakis K, Synnefa A, Livada I. Development and testing of thermochromic coatings for buildings and urban structures. Solar Energy. 2009;83:538-51.

[24] Ma Y, Zhang X, Zhu B, Wu K. Research on reversible effects and mechanism between the energy-absorbing and energy-reflecting states of chameleon-type building coatings. Solar Energy. 2002;72:511-20.

[25] Getter KL, Rowe DB. The role of extensive green roofs in sustainable development. HortSci. 2006;41:1276-85.

[26] Oberndorfer E, Lundholm J, Bass B, Coffman RR, Doshi H, Dunnett N, et al. Green roofs as urban ecosystems: Ecological structures, functions, and services. BioSci. 2007;57:823-33.

[27] Yang J, Wang Z-H, Chen F, Miao S, Tewari M, Voogt JA, et al. Enhancing hydrological modelling in the coupled Weather Research and Forecasting-urban modelling system. Boundary-Layer Meteorol. 2014; doi: 10.1007/s10546-014-9991-6. 
[28] Dvorak B, Volder A. Green roof vegetation for North American ecoregions: A literature review. Landsc Urban Plan. 2010;96:197-213.

[29] Yang J, Wang Z-H. Physical parameterization and sensitivity of urban hydrological models: Application to green roof systems. Build Environ. 2014;75:250-63.

[30] Akbari H, Pomerantz M, Taha H. Cool surfaces and shade trees to reduce energy use and improve air quality in urban areas. Solar energy. 2001;70:295-310.

[31] Shashua-Bar L, Hoffman M. Vegetation as a climatic component in the design of an urban street: An empirical model for predicting the cooling effect of urban green areas with trees. Energy Build. 2000;31:221-35.

[32] Geros V, Santamouris M, Karatasou S, Tsangrassoulis A, Papanikolaou N. On the cooling potential of night ventilation techniques in the urban environment. Energy Build. 2005;37:243-57.

[33] Mihalakakou G, Santamouris M, Asimakopoulos D. Use of the ground for heat dissipation. Energy. 1994;19:17-25.

[34] Doulos L, Santamouris M, Livada I. Passive cooling of outdoor urban spaces. The role of materials. Solar Energy. 2004;77:231-49.

[35] Santamouris M. Cooling the cities - A review of reflective and green roof mitigation technologies to fight heat island and improve comfort in urban environments. Solar Energy. 2014;103:682-703.

[36] Santamouris M, Synnefa A, Karlessi T. Using advanced cool materials in the urban built environment to mitigate heat islands and improve thermal comfort conditions. Solar Energy. 
2011;85:3085-102.

[37] Akbari H, Matthews HD. Global cooling updates: Reflective roofs and pavements. Energy Build. 2012;55:2-6.

[38] Akbari H, Levinson R. Evolution of cool-roof standards in the US. Adv Build Energy Res. 2008;2:1-32.

[39] Santamouris M. Using cool pavements as a mitigation strategy to fight urban heat island-A review of the actual developments. Renew Sustain Energy Rev. 2013;26:224-40.

[40] Akbari H, Menon S, Rosenfeld A. Global cooling: increasing world-wide urban albedos to offset CO2. Climatic Change. 2008;94:275-86.

[41] Akbari H, Matthews HD, Seto D. The long-term effect of increasing the albedo of urban areas. Environ Res Lett. 2012;7:024004.

[42] Sproul J, Wan MP, Mandel BH, Rosenfeld AH. Economic comparison of white, green, and black flat roofs in the United States. Energy Build. 2014;71:20-7.

[43] Boriboonsomsin K, Reza F. Mix design and benefit evaluation of high solar reflectance concrete for pavements. Transport Res Rec: J Transport Res Board. 2007;2011:11-20.

[44] California Energy Commission. Building energy efficiency standards for residential and nonresidential buildings. California Code of Regulations, Title 24. 2008.

[45] Grimm NB, Faeth SH, Golubiewski NE, Redman CL, Wu J, Bai X, et al. Global change and the ecology of cities. Science. 2008;319:756-60.

[46] Georgescu M, Mahalov A, Moustaoui M. Seasonal hydroclimatic impacts of Sun Corridor expansion. Environ Res Lett. 2012;7:034026. 
[47] Georgescu M, Morefield PE, Bierwagen BG, Weaver CP. Urban adaptation can roll back warming of emerging megapolitan regions. Proc Natl Acad Sci USA. 2014;111:2909-14.

[48] Taha H. Meso-urban meteorological and photochemical modeling of heat island mitigation. Atmos Environ. 2008;42:8795-809.

[49] Taha H. Meteorological, emissions and air-quality modeling of heat-island mitigation: recent findings for California, USA. Int J Low-Carbon Technol. 2013: ctt010.

[50] Taha H, Konopacki S, Gabersek S. Impacts of large-scale surface modifications on meteorological conditions and energy use: A 10-region modeling study. Theor Appl Climatol. 1999;62:175-85.

[51] Takebayashi H, Moriyama M. Surface heat budget on green roof and high reflection roof for mitigation of urban heat island. Build Environ. 2007;42:2971-9.

[52] Susca T, Gaffin SR, Dell’Osso GR. Positive effects of vegetation: Urban heat island and green roofs. Environ Pollut. 2011;159:2119-26.

[53] Synnefa A, Santamouris M, Livada I. A study of the thermal performance of reflective coatings for the urban environment. Solar Energy. 2006;80:968-81.

[54] Santamouris M, Gaitani N, Spanou A, Saliari M, Giannopoulou K, Vasilakopoulou K, et al. Using cool paving materials to improve microclimate of urban areas - Design realization and results of the flisvos project. Build Environ. 2012;53:128-36.

[55] Levinson RM. Near-ground cooling efficacies of trees and high-albedo surfaces. Ph.D. Thesis, University of California, Berkeley, 148 pp. 1997.

[56] Li H. Evaluation of cool pavement strategies for heat island mitigation. Ph.D. Thesis, 36 
University of California, Davis, 367 pp. 2013.

[57] Brender D, Lindsey T. Effect of rooftop exposure in direct sunlight on conduit ambient temperatures. Conference Record of the 2006 IEEE. 2006;2:705-11.

[58] Synnefa A, Karlessi T, Gaitani N, Santamouris M, Assimakopoulos DN, Papakatsikas C. Experimental testing of cool colored thin layer asphalt and estimation of its potential to improve the urban microclimate. Build Environ. 2011;46:38-44.

[59] Zhou Y, Shepherd JM. Atlanta's urban heat island under extreme heat conditions and potential mitigation strategies. Nat Hazards. 2010;52:639-68.

[60] Yaghoobian N, Kleissl J. Effect of reflective pavements on building energy use. Urban Climate. 2012;2:25-42.

[61] Romeo C, Zinzi M. Impact of a cool roof application on the energy and comfort performance in an existing non-residential building. A Sicilian case study. Energy Build. 2013;67:647-57.

[62] Shahidan MF, Jones PJ, Gwilliam J, Salleh E. An evaluation of outdoor and building environment cooling achieved through combination modification of trees with ground materials. Build Environ. 2012;58:245-57.

[63] Jacobson MZ, Ten Hoeve JE. Effects of urban surfaces and white roofs on global and regional climate. J Climate. 2012;25:1028-44.

[64] Georgakis C, Santamouris M. Experimental investigation of air flow and temperature distribution in deep urban canyons for natural ventilation purposes. Energy Build. 2006;38:367-76. 
[65] Chen H, Ooka R, Huang H, Tsuchiya T. Study on mitigation measures for outdoor thermal environment on present urban blocks in Tokyo using coupled simulation. Build Environ. 2009;44:2290-9.

[66] Sakka A, Santamouris M, Livada I, Nicol F, Wilson M. On the thermal performance of low income housing during heat waves. Energy Build. 2012;49:69-77.

[67] Kilbourne EM. Heat-related illness: Current status of prevention efforts. Am J Prev Med. 2002;22:328-9.

[68] Harlan SL, Brazel AJ, Prashad L, Stefanov WL, Larsen L. Neighborhood microclimates and vulnerability to heat stress. Soc Sci Med. 2006;63:2847-63.

[69] Rizwan AM, Dennis LYC, Liu C. A review on the generation, determination and mitigation of urban heat island. J Environ Sci. 2008;20:120-8.

[70] Kim Y-H, Baik J-J. Spatial and temporal structure of the urban heat island in Seoul. J Appl Meteorol. 2005;44:591-605.

[71] Magee N, Curtis J, Wendler G. The urban heat island effect at Fairbanks, Alaska. Theor Appl Climatol. 1999;64:39-47.

[72] Chow WTL, Brennan D, Brazel AJ. Urban heat island research in Phoenix, Arizona: Theoretical contributions and policy applications. B Amer Meteorol Soc. 2011;93:517-30.

[73] Miao S, Chen F, LeMone MA, Tewari M, Li Q, Wang Y. An observational and modeling study of characteristics of urban heat island and boundary layer structures in Beijing. J Appl Meteorol Climatol. 2009;48:484-501.

[74] Streutker DR. Satellite-measured growth of the urban heat island of Houston, 
Texas. Remote Sens Environ. 2003;85:282-9.

[75] Kolokotroni M, Giridharan R. Urban heat island intensity in London: An investigation of the impact of physical characteristics on changes in outdoor air temperature during summer. Solar Energy. 2008;82:986-98.

[76] Morris CJG, Simmonds I, Plummer N. Quantification of the influences of wind and cloud on the nocturnal urban heat island of a large city. J Appl Meteorol. 2001;40:169-82.

[77] Jauregui E. Heat island development in Mexico City. Atmos Environ. 1997;31:3821-31.

[78] Gaffin SR, Rosenzweig C, Khanbilvardi R, Parshall L, Mahani S, Glickman H, et al. Variations in New York City's urban heat island strength over time and space. Theor Appl Climatol. 2008;94:1-11.

[79] Gedzelman SD, Austin S, Cermak R, Stefano N, Partridge S, Quesenberry S, Robinson DA. Mesoscale aspects of the urban heat island around New York City. Theor Appl Climatol. 2003;75:29-42.

[80]Sarkar A, De Ridder K. The urban heat island intensity of Paris: a case study based on a simple urban surface parametrization. Boundary-Layer Meteorol. 2011;138:511-20.

[81] Hawkins TW, Brazel AJ, Stefanov WL, Bigler W, Saffell EM. The role of rural variability in urban heat island determination for Phoenix, Arizona. J Appl Meteorol. 2004;43:476-86.

[82] Brazel AJ, Gober P, Lee S, Grossman-Clarke S, Zehnder J, Hedquist B, et al. Dynamics and determinants of urban heat island change (1990-2004) with Phoenix, Arizona, USA. Clim. Res. 2007;33:171-82.

[83] Chow WT, Roth M. Temporal dynamics of the urban heat island of Singapore. Int J 
Climatol. 2006;26:2243-60.

[84] Saitoh TS, Shimada T, Hoshi H. Modeling and simulation of the Tokyo urban heat island. Atmos Environ. 1996;30:3431-42.

[85] Arnfield AJ. Two decades of urban climate research: a review of turbulence, exchanges of energy and water, and the urban heat island. Int J Climatol. 2003;23:1-26.

[86] Hafner J, Kidder SQ. Urban heat island modeling in conjunction with satellite-derived surface/soil parameters. J Appl Meteorol. 1999;38:448-65.

[87] Jauregui E. Heat island development in Mexico City. Atmos Environ. 1997;31:3821-31.

[88] Vez JPM, Rodriguez A, Jiménez JI. A study of the Urban Heat Island of Granada. Int J Climatol. 2000;20:899-911.

[89] Oke TR. The energetic basis of the urban heat island. Q J Roy Meteorol Soc. 1982;108:1-24.

[90] Ryu Y-H, Baik J-J. Quantitative analysis of factors contributing to urban heat island intensity. J Appl Meteorol Climatol. 2012;51:842-54.

[91] Millstein D, Menon S. Regional climate consequences of large-scale cool roof and photovoltaic array deployment. Environ Res Lett. 2011;6:034001.

[92] Retzlaff RC. Green building assessment systems: A framework and comparison for planners. J Am Plan Assoc. 2008;74:505-19.

[93] Akbari H, Davis S, Dorsano S, Huang J, Winett S. Cooling our communities-A guidebook on tree planting and light colored surfacing. US Environmental Protection Agency Office of Policy Analysis, Climate change division. 1992.

[94] Santamouris M, Papanikolaou N, Livada I, Koronakis I, Georgakis C, Argiriou A, et al. On 
the impact of urban climate on the energy consumption of buildings. Solar Energy. 2001;70:201-16.

[95] Akbari H, Konopacki S, Pomerantz M. Cooling energy savings potential of reflective roofs for residential and commercial buildings in the United States. Energy. 1999;24:391-407.

[96] Akbari H, Konopacki S. Calculating energy-saving potentials of heat-island reduction strategies. Energy Policy. 2005;33:721-56.

[97] Levinson R, Akbari H. Potential benefits of cool roofs on commercial buildings: conserving energy, saving money, and reducing emission of greenhouse gases and air pollutants. Energy Effic. 2009;3:53-109.

[98] Synnefa A, Santamouris M, Akbari H. Estimating the effect of using cool coatings on energy loads and thermal comfort in residential buildings in various climatic conditions. Energy Build. 2007;39:1167-74.

[99] Oleson KW, Bonan GB, Feddema J. Effects of white roofs on urban temperature in a global climate model. Geophys Res Lett. 2010;37.

[100] Yaghoobian N, Kleissl J, Krayenhoff ES. Modeling the thermal effects of artificial turf on the urban environment. J Appl Meteorol Climatol. 2010;49:332-45.

[101] Skamarock WC, Klemp JB. A time-split nonhydrostatic atmospheric model for weather research and forecasting applications. J Comput Phys. 2008;227:3465-85.

[102] Shamarock W, Klemp JB, Dudhia J, Gill DO, Barker DM, Duda M, et al. A description of the advanced research WRF version 3. NCAR technical note. 2008.

[103] Masson V. A physically-based scheme for the urban energy budget in atmospheric models. 
Boundary-Layer Meteorol. 2000;94:357-97.

[104] Kusaka H, Kondo H, Kikegawa Y, Kimura F. A simple single-layer urban canopy model for atmospheric models: comparison with multi-layer and slab models. Boundary-Layer Meteorol. 2001;101:329-58.

[105] Lee S-H, Park S-U. A vegetated urban canopy model for meteorological and environmental modelling. Boundary-Layer Meteorol. 2008;126:73-102.

[106] Wang Z-H, Bou-Zeid E, Smith J. A spatially-analytical scheme for surface temperatures and conductive heat fluxes in urban canopy models. Boundary-Layer Meteorol. 2011;138:171-93.

[107] Wang Z-H, Bou-Zeid E, Smith JA. A coupled energy transport and hydrological model for urban canopies evaluated using a wireless sensor network. Q J Roy Meteorol Soc. 2013;139:1643-57.

[108] Martilli A, Clappier A, Rotach M. An urban surface exchange parameterisation for mesoscale models. Boundary-Layer Meteorol. 2002;104:261-304.

[109] Kondo H, Genchi Y, Kikegawa Y, Ohashi Y, Yoshikado H, Komiyama H. Development of a multi-layer urban canopy model for the analysis of energy consumption in a big city: Structure of the urban canopy model and its basic performance. Boundary-Layer Meteorol. 2005;116:395-421.

[110] Salamanca F, Krpo A, Martilli A, Clappier A. A new building energy model coupled with an urban canopy parameterization for urban climate simulations-part I. formulation, verification, and sensitivity analysis of the model. Theor Appl Climatol. 2010;99:331-44. 
[111] Salamanca F, Martilli A, Tewari M, Chen F. A study of the urban boundary layer using different urban parameterizations and high-resolution urban canopy parameters with WRF. J Appl Meteorol Climatol. 2010;50:1107-28.

[112] Lawrence Berkeley National Laboratory. Getting started with EnergyPlus: Basic concepts manual. 2013.

[113] Lawrence Berkeley National Laboratory. Input output reference: The encyclopedic reference to EnergyPlus input and output. 2013.

[114] Grimmond CSB, Blackett M, Best MJ, Barlow J, Baik JJ, Belcher SE, et al. The international urban energy balance models comparison project: First results from Phase 1. J Appl Meteorol Climatol. 2010;49:1268-92.

[115] Grimmond CSB, Blackett M, Best MJ, Baik JJ, Belcher SE, Beringer J, et al. Initial results from Phase 2 of the international urban energy balance model comparison. Int J Climatol. 2011;31:244-72.

[116] Scherba A, Sailor DJ, Rosenstiel TN, Wamser CC. Modeling impacts of roof reflectivity, integrated photovoltaic panels and green roof systems on sensible heat flux into the urban environment. Build Environ. 2011;46:2542-51.

[117] Bala G, Nag B. Albedo enhancement over land to counteract global warming: impacts on hydrological cycle. Climate Dyn. 2011;39:1527-42.

[118] Vörösmarty CJ, Green P, Salisbury J, Lammers RB. Global water resources: Vulnerability from climate change and population growth. Science. 2000;289:284-8.

[119] Standard ASHRAE. 55, Thermal environmental conditions for human occupancy. 
American Society of Heating, Refrigerating and Air conditioning Engineers. 1992;145.

[120] Zinzi M, Agnoli S. Cool and green roofs. An energy and comfort comparison between passive cooling and mitigation urban heat island techniques for residential buildings in the Mediterranean region. Energy Build. 2012;55:66-76.

[121] Fintikakis N, Gaitani N, Santamouris M, Assimakopoulos M, Assimakopoulos DN, Fintikaki M, et al. Bioclimatic design of open public spaces in the historic centre of Tirana, Albania. Sustain Cities Soc. 2011;1:54-62.

[122] Givoni B. Estimation of the effect of climate on man: Development of a new thermal index. Technion-IIT, Building Research Station. 1963.

[123] Höppe P. The physiological equivalent temperature - a universal index for the biometeorological assessment of the thermal environment. Int J Biometeorol. 1999;43:71-5.

[124] Lynn BH, Carlson TN, Rosenzweig C, Goldberg R, Druyan L, Cox J, et al. A modification to the NOAH LSM to simulate heat mitigation strategies in the New York City metropolitan area. J Appl Meteorol Climatol. 2009;48:199-216.

[125] Erell E, Pearlmutter D, Boneh D, Kutiel PB. Effect of high-albedo materials on pedestrian heat stress in urban street canyons. Urban Climate. 2013.

[126] Pearlmutter D, Berliner P, Shaviv E. Physical modeling of pedestrian energy exchange within the urban canopy. Build Environ. 2006;41:783-95.

[127] Levinson R, Berdahl P, Akbari H. Solar spectral optical properties of pigments-Part I: model for deriving scattering and absorption coefficients from transmittance and reflectance measurements. Sol Energy Mater and Sol Cells. 2005;89:319-49. 
[128] Berdahl P, Bretz SE. Preliminary survey of the solar reflectance of cool roofing materials. Energy Build. 1997;25:149-58.

[129] Levinson R, Berdahl P, Akbari H, Miller W, Joedicke I, Reilly J, et al. Methods of creating solar-reflective nonwhite surfaces and their application to residential roofing materials. Solar Energy Mater and Sol Cells. 2007;91:304-14.

[130] Canadian Center for Occupational Health and Safety. Skin Cancer and Sunlight. http://wwwccohsca/oshanswers/diseases/skin_cancerhtml. Retrieved July 3rd, 2008.

[131] Taha H. Urban surface modification as a potential ozone air-quality improvement strategy in california: Phase one, initial mesoscale modeling: PIER final project report. California Energy Commission. 2005.

[132] Lawrence Berkeley National Laboratory. Cool Science: Cool Roofs. http://heatisland.lbl.gov/coolscience/cool-science-cool-roofs. Retrieved July 3rd, 2008. [133] City of Chula Vista. Cool roof study final report. http://www.chulavistaca.gov/clean/PDF/CVCoolPavementsStudy_DRAFT9-7-12.pdf. 2012. [134] James HP. Brecon Beacons National Park International Dark Sky Reserve lighting management plan.

http://wwwdarkskyorg/assets/Night_Sky_Conservation/BBNPA\%20LMP\%20completepdf. 2013.

[135] Cohen AJ, Anderson HR, Ostro B, Pandey KD, Krzyzanowski M, Künzli N, et al. Urban air pollution. Comp Quantif of Health Risks. 2004;2:1353-433.

[136] Walcek CJ, Yuan HH. Calculated influence of temperature-related factors on ozone 45 
formation rates in the lower troposphere. J Appl Meteorol. 1995;34:1056-69.

[137] Kalabokas PD, Viras LG, Bartzis JG, Repapis CC. Mediterranean rural ozone characteristics around the urban area of Athens. Atmos Environ. 2000;34:5199-208.

[138] Taha H. Modeling the impacts of large-scale albedo changes on ozone air quality in the South Coast Air Basin. Atmos Environ. 1997;31:1667-76.

[139] Taha H. Urban surface modification as a potential ozone air-quality improvement strategy in California: A mesoscale modelling study. Boundary-Layer Meteorol. 2008;127:219-39.

[140] Taha H. Urban surface modification as a potential ozone air-quality improvement strategy in California-Phase 2: Fine-resolution meteorological and photochemical modeling of urban heat islands. Final report prepared by Altostratus Inc for the California Energy Commission, Sacramento, California, PIER Environmental Research. 2007.

[141] Rosenfeld AH, Akbari H, Romm JJ, Pomerantz M. Cool communities: strategies for heat island mitigation and smog reduction. Energy Build. 1998;28:51-62.

[142] Sailor DJ. Simulated urban climate response to modifications in surface albedo and vegetative cover. J Appl Meteorol. 1995;34:1694-704.

[143] Botham D, Hoang T, Cal RB, Sailor DJ. Evaluating the thermal footprint of rooftop heat island mitigation strategies. American Meteorological Society annual meeting. 2014.

[144] Giorgi F, Francisco R. Evaluating uncertainties in the prediction of regional climate change. Geophys Res Lett. 2000;27:1295-8.

[145] Murphy JM, Sexton DM, Barnett DN, Jones GS, Webb MJ, Collins M, et al. Quantification of modelling uncertainties in a large ensemble of climate change simulations. 
Nature. 2004;430:768-72.

[146] Kripalani RH, Oh JH, Kulkarni A, Sabade SS, Chaudhari HS. South Asian summer monsoon precipitation variability: Coupled climate model simulations and projections under IPCC AR4. Theor Appl Climatol. 2007;90:133-59.

[147] Paek H, Huang H-P. A comparison of the interannual variability in atmospheric angular momentum and length-of-day using multiple reanalysis data sets. J Geophys Res: Atmos. 2012;117:D20102.

[148] Paek H, Huang H-P. A comparison of decadal-to-interdecadal variability and trend in reanalysis datasets using atmospheric angular momentum. J Climate. 2012;25:4750-8.

[149] Kistler R, Collins W, Saha S, White G, Woollen J, Kalnay E, et al. The NCEP-NCAR 50year reanalysis: Monthly means CD-ROM and documentation. B Am Meteorol Soc. 2001;82:247-67.

[150] Kanamitsu M, Ebisuzaki W, Woollen J, Yang S-K, Hnilo JJ, Fiorino M, et al. NCEP-DOE AMIP-II reanalysis (R-2). B Amer Meteorol Soc. 2002;83:1631-43.

[151] Saha S, Moorthi S, Pan H-L, Wu X, Wang J, Nadiga S, et al. The NCEP climate forecast system reanalysis. B Amer Meteorol Soc. 2010;91:1015-57.

[152] Uppala SM, KÅllberg PW, Simmons AJ, Andrae U, Bechtold VDC, Fiorino M, et al. The ERA-40 re-analysis. Q J Roy Meteorol Soc. 2005;131:2961-3012.

[153] Compo GP, Whitaker JS, Sardeshmukh PD, Matsui N, Allan RJ, Yin X, et al. The twentieth century reanalysis project. Q J Roy Meteorol Soc. 2011;137:1-28.

[154] Rienecker MM, Suarez MJ, Gelaro R, Todling R, Bacmeister J, Liu E, et al. MERRA: 
NASA's modern-era retrospective analysis for research and applications. J Climate. 2011;24:3624-48.

[155] Krishnamurti TN, Kishtawal CM, Zhang Z, LaRow T, Bachiochi D, Williford E, et al. Multimodel ensemble forecasts for weather and seasonal climate. J Climate. 2000;13:4196-216. [156] Giorgi F, Mearns LO. Calculation of average, uncertainty range, and reliability of regional climate changes from AOGCM simulations via the "Reliability Ensemble Averaging” (REA) method. J Climate. 2002;15:1141-58.

[157] Solecki WD, Rosenzweig C, Parshall L, Pope G, Clark M, Cox J, et al. Mitigation of the heat island effect in urban New Jersey. Environ Hazards. 2005;6:39-49.

[158] Ray S, Glicksman L. Potential energy savings of various roof technologies. ASHRAE Transactions. 2010:1-12.

[159] Sailor DJ, Elley TB, Gibson M. Exploring the building energy impacts of green roof design decisions - a modeling study of buildings in four distinct climates. J Build Phys. 2011: 1744259111420076.

[160] Simmons M, Gardiner B, Windhager S, Tinsley J. Green roofs are not created equal: the hydrologic and thermal performance of six different extensive green roofs and reflective and non-reflective roofs in a sub-tropical climate. Urban Ecosyst. 2008;11:339-48.

[161] Saiz S, Kennedy C, Bass B, Pressnail K. Comparative life cycle assessment of standard and green roofs. Environ Sci Technol. 2006;40:4312-6.

[162] Simpson JR, McPherson EG. The effects of roof albedo modification on cooling loads of scale model residences in Tucson, Arizona. Energy Build. 1997;25:127-37. 
[163] Viguié V, Hallegatte S. Trade-offs and synergies in urban climate policies. Nat Climate Change. 2012;2:334-7.

[164] Gui J, Phelan P, Kaloush K, Golden J. Impact of pavement thermophysical properties on surface temperatures. J Mat in Civil Eng. 2007;19:683-90.

[165] Menon S, Akbari H, Mahanama S, Sednev I, Levinson R. Radiative forcing and temperature response to changes in urban albedos and associated $\mathrm{CO}^{2}$ offsets. Environ Res Lett. 2010;5:014005.

[166] Synnefa A, Saliari M, Santamouris M. Experimental and numerical assessment of the impact of increased roof reflectance on a school building in Athens. Energy Build. 2012;55:7-15. [167] Gaffin S, Rosenzweig C, Parshall L, Beattie D, Berghage R, O’Keeffe G, et al. Energy balance modeling applied to a comparison of white and green roof cooling efficiency. Green Roofs in the New York Metropolitan Region Research Report. 2010;7.

[168] Taha H, Sailor D, Akbari H. High-albedo materials for reducing building cooling energy use (No. LBL-31721). Lawrence Berkeley National Lab, CA (United States). 1992.

[169] Pomerantz M, Akbari H, Chen A, Taha H, Rosenfeld AH. Paving materials for heat island mitigation (No. LBL--38074). Lawrence Berkeley National Lab, CA (United States). 1997.

[170] Akbari H. Measured energy savings from the application of reflective roofs in two small non-residential buildings. Energy. 2003;28:953-67.

[171] Akbari H, Levinson R, Rainer L. Monitoring the energy-use effects of cool roofs on California commercial buildings. Energy Build. 2005;37:1007-16.

[172] Suehrcke H, Peterson EL, Selby N. Effect of roof solar reflectance on the building heat 
gain in a hot climate. Energy Build. 2008;40:2224-35.

[173] Jo JH, Carlson JD, Golden JS, Bryan H. An integrated empirical and modeling methodology for analyzing solar reflective roof technologies on commercial buildings. Build Environ. 2010;45:453-60.

[174] Sailor DJ, Kalkstein LS, Wong E. The potential of urban heat island mitigation to alleviate heat related mortality: methodological overview and preliminary modeling results for Philadelphia. In: Proceedings of the 4th Symposium on the Urban Environment, Norfolk, VA, pp 68-69. 2002.

[175] Rosenzweig C, Solecki W, Slosberg R. Mitigating New York City’s heat island with urban forestry, living roofs, and light surfaces. A report to the New York State Energy Research and Development Authority. 2006.

[176] Akbari H, Bretz S, Kurn DM, Hanford J. Peak power and cooling energy savings of high-albedo roofs. Energy Build. 1997;25:117-26.

[177] Parker DS, Barkaszi Jr SF. Roof solar reflectance and cooling energy use: field research results from Florida. Energy Build. 1997;25:105-15.

[178] Akbari H, Konopacki S. Energy effects of heat-island reduction strategies in Toronto, Canada. Energy. 2004;29:191-210.

[179] Bianchi MV, Desjarlais AO, Miller WA, Petrie PTW. Cool roofs and thermal insulation: energy savings and peak demand reduction. In Proceedings of the ASHRAE Conference in Thermal Performance of the Exterior Envelopes of Buildings X. 2007.

[180] Synnefa A, Santamouris M. Advances on technical, policy and market aspects of cool roof 
technology in Europe: The Cool Roofs project. Energy Build. 2012;55:35-41. 
(a)

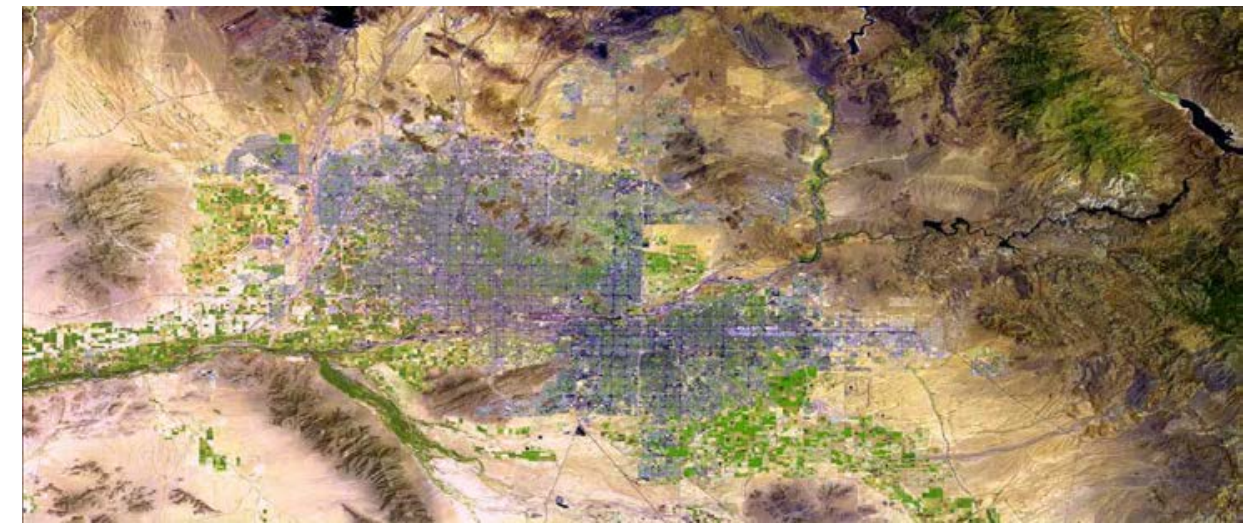

(b)

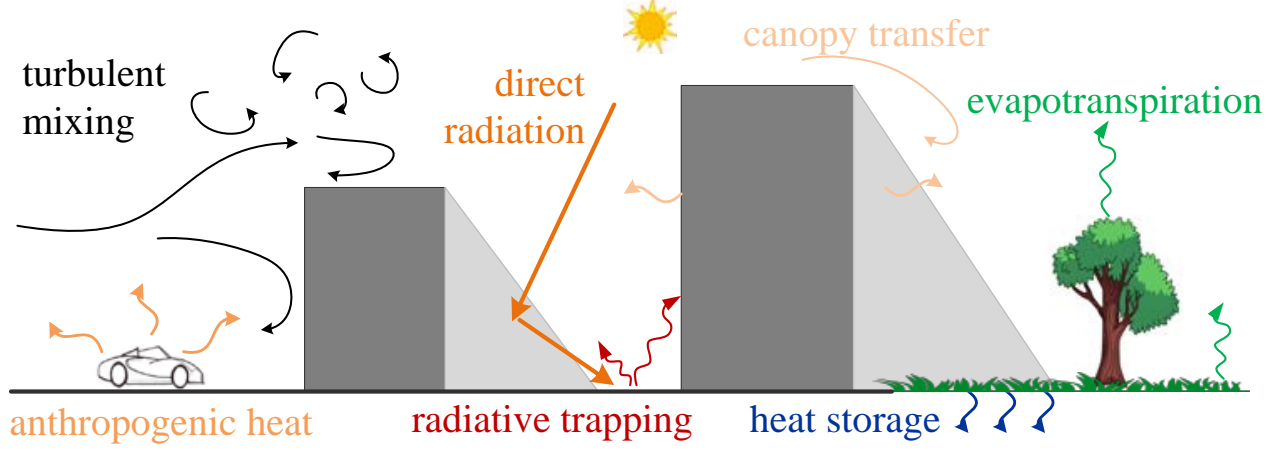

(c)

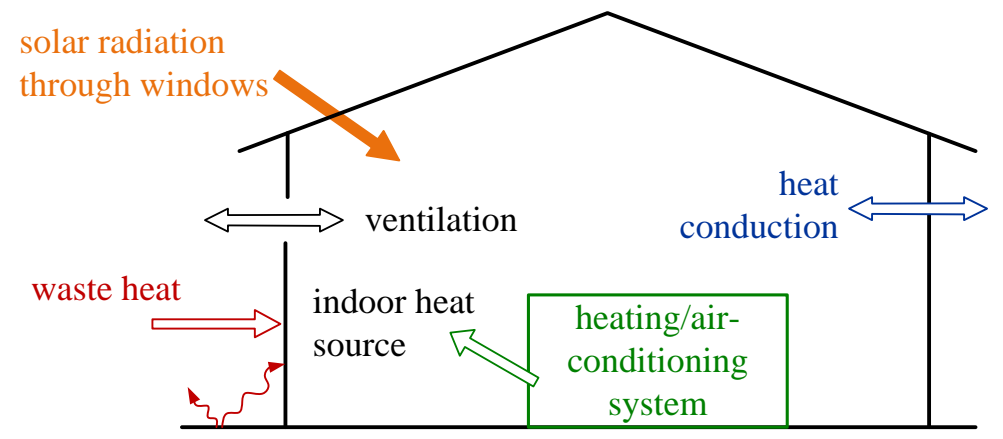

Figure1: Schematic of multiscale involved in numerical modeling: (a) city scale (characteristic length of $\left.\sim 10^{3}-10^{4} \mathrm{~m}\right)$, (b) neighborhood scale $\left(\sim 10^{2}-10^{3} \mathrm{~m}\right)$, and (c) building scale $\left(\sim 10-10^{2} \mathrm{~m}\right)$ 
Table 1. Summary of impacts on surface temperature by reflective materials from simulation studies

\begin{tabular}{|c|c|c|c|}
\hline Reference & Methodology & Albedo increase & Temperature change \\
\hline [48] & uMM5 and CAMx & $\begin{array}{l}0.1,0.25 \text { and } 0.08 \text { on roof, wall and paved } \\
\text { surfaces in urban areas }\end{array}$ & Reduction of up to $10^{\circ} \mathrm{C}$ during the summer in Sacramento, California \\
\hline$[54]$ & $\begin{array}{l}\text { CFD simulation and } \\
\text { TRNSYS }\end{array}$ & $\begin{array}{l}0.12 \text { in an urban park of } 4500 \mathrm{~m}^{2} \text { in the } \\
\text { greater Athens area }\end{array}$ & Reduction of up to $12{ }^{\circ} \mathrm{C}$ during a typical summer day \\
\hline$[60]$ & TUF-IOBES & 0.4 on ground & Reduction of up to $15.8{ }^{\circ} \mathrm{C}$ at $2 \mathrm{PM}$ in canopy with aspect ratio of 0.37 \\
\hline [91] & WRF v3.2.1 & $\begin{array}{l}0.25 \text { and } 0.15 \text { for roofs and pavements in } \\
\text { urban areas over the continental U.S. }\end{array}$ & $\begin{array}{l}\text { Summer afternoon temperature in urban locations reduces by } 0.11-0.53{ }^{\circ} \mathrm{C} \text {, } \\
\text { some rural locations show temperature increases of up to } 0.27{ }^{\circ} \mathrm{C}\end{array}$ \\
\hline$[100]$ & TUF3D & $\begin{array}{l}\text { Albedo is } 0.08,0.18 \text { and } 0.35 \text { on artificial } \\
\text { turf (AT), asphalt and concrete }\end{array}$ & $\begin{array}{l}\text { Daily maximum surface temperature is the lowest on concrete and the } \\
\text { highest on AT surface }\end{array}$ \\
\hline [164] & $\begin{array}{l}\text { One-dimensional } \\
\text { Mathematic model }\end{array}$ & Up to 0.4 & $\begin{array}{l}\text { Average maximum temperature reduces by up to } 18^{\circ} \mathrm{C} \text {, average minimum } \\
\text { temperature reduces by up to } 3{ }^{\circ} \mathrm{C}\end{array}$ \\
\hline$[165]$ & CLSM & 0.1 over global urban areas & $\begin{array}{l}\text { Reduction of about } 0.008 \text { and } 0.03{ }^{\circ} \mathrm{C} \text { in average land surface temperature } \\
\text { worldwide and over continental U.S. during boreal summer }\end{array}$ \\
\hline$[166]$ & TRNSYS & 0.69 on a $410 \mathrm{~m}^{2}$ school roof in Athens & Reduction of up to $25{ }^{\circ} \mathrm{C}$ during summer \\
\hline [167] & Energy Balance Model & 0.15 on roof & Reduction of up to about $15{ }^{\circ} \mathrm{F}$ in July, 2003 \\
\hline
\end{tabular}


Table 2. Summary of impacts on surface temperature by reflective materials from experiments

\begin{tabular}{|c|c|c|c|}
\hline Reference & Methodology & Albedo measurement & Temperature change \\
\hline [34] & $\begin{array}{l}\text { Compare } 93 \text { commonly used pavement } \\
\text { materials }(40 \mathrm{~cm} \times 40 \mathrm{~cm})\end{array}$ & Not available & $\begin{array}{l}\text { Lowest daily surface temperature on white marble, highest } \\
\text { temperature on asphalt surface during summer }\end{array}$ \\
\hline [51] & $\begin{array}{l}\text { Monitor roof surface units in Japan during } \\
2004\end{array}$ & $\begin{array}{l}0.36 \text { on gray paint and } 0.74 \text { on white } \\
\text { paint }\end{array}$ & $\begin{array}{l}\text { Daytime temperature of gray paint is almost } 10{ }^{\circ} \mathrm{C} \text { higher than that } \\
\text { of white paint in August. Difference is smaller in November }\end{array}$ \\
\hline [52] & $\begin{array}{l}\text { Monitor white and black roofs in New } \\
\text { York during } 2009\end{array}$ & 0.05 and 0.6 on black and white roofs & Reduction of about $10{ }^{\circ} \mathrm{C}$ in winter and about $30{ }^{\circ} \mathrm{C}$ in summer \\
\hline [53] & $\begin{array}{l}\text { Compare } 14 \text { types of reflective coatings } \\
\text { on white concrete pavement tiles }(40 \mathrm{~cm} \times \\
40 \mathrm{~cm})\end{array}$ & $\begin{array}{l}\text { Not available, coating colors include } \\
\text { white, silver, silver gray and black }\end{array}$ & $\begin{array}{l}\text { Maximum reductions in mean daily surface temperature and mean } \\
\text { maximum daily surface temperature are } 5{ }^{\circ} \mathrm{C} \text { and } 7.5^{\circ} \mathrm{C} \text { from } \\
\text { August to October } 2004 \text {, both found on white coatings }\end{array}$ \\
\hline [54] & $\begin{array}{l}\text { Apply reflective pavements in an urban } \\
\text { park in the greater Athens }\end{array}$ & $\begin{array}{l}0.48 \text { and } 0.6 \text { before and after } \\
\text { deployment }\end{array}$ & $\begin{array}{l}\text { Maximum reduction under non-shaded condition is } 5.4 \text { and } 7.6{ }^{\circ} \mathrm{C} \\
\text { for the first and second monitoring day }\end{array}$ \\
\hline [56] & $\begin{array}{l}\text { Measure nine sections }(4 \mathrm{~m} \times 4 \mathrm{~m}) \text { of } \\
\text { different pavement types }\end{array}$ & $\begin{array}{l}0.18-0.29 \text { on concrete and paver, } 0.08 \\
\text { to } 0.09 \text { on asphalt }\end{array}$ & $\begin{array}{l}\text { Reduction of } 10-25^{\circ} \mathrm{C} \text { in peak surface temperature by concrete and } \\
\text { paver pavement during hot summer in Davis, California }\end{array}$ \\
\hline [58] & $\begin{array}{l}\text { Compare thin layer asphalt samples }(33 \mathrm{~cm} \\
\times 33 \mathrm{~cm}) \text { of different colors to } \\
\text { conventional black asphalt }\end{array}$ & $\begin{array}{l}0.04,0.27,0.40,0.45 \text { and } 0.55 \text { on } \\
\text { black, red and green, yellow, beige and } \\
\text { off-white colors }\end{array}$ & $\begin{array}{l}\text { Reduction of up to } 7.7 \text { and } 11.9{ }^{\circ} \mathrm{C} \text { in mean diurnal surface } \\
\text { temperature and mean maximum diurnal surface temperature by } \\
\text { off-white asphalt compared to black conventional asphalt }\end{array}$ \\
\hline [61] & Install a cool roof in Sicily & 0.86 after installation & Reduction of up to $20^{\circ} \mathrm{C}$ from April to September, 2009 \\
\hline [160] & Monitor white and black roofs in Austin & Not available & Reduction of $26^{\circ} \mathrm{C}$ by white roof in midafternoon on a warm day \\
\hline [162] & $\begin{array}{l}\text { Monitor three } 1 / 4 \text {-scale model houses under } \\
\text { clear hot day condition }\end{array}$ & $\begin{array}{l}0.75,0.3,0.5 \text { and } 0.1 \text { on white, gray, } \\
\text { silver and brown roofs }\end{array}$ & $\begin{array}{l}\text { White roof is up to } 20^{\circ} \mathrm{C} \text { cooler than gray or silver roof, and is up } \\
\text { to } 30^{\circ} \mathrm{C} \text { cooler than brown roof }\end{array}$ \\
\hline [168] & $\begin{array}{l}\text { Monitor various materials in California } \\
\text { during } 1991\end{array}$ & $\begin{array}{l}0.72 \text { and } 0.08 \text { on white and black } \\
\text { coatings }\end{array}$ & $\begin{array}{l}\text { Reduction of } 45^{\circ} \mathrm{C} \text { in early afternoon on clear and warm days in } \\
\text { July }\end{array}$ \\
\hline [169] & $\begin{array}{l}\text { Monitor different pavements in September } \\
\text { in Berkeley }\end{array}$ & $\begin{array}{l}0.05,0.15 \text { and } 0.50 \text { on concrete, } \\
\text { asphalt and white coating asphalt }\end{array}$ & $\begin{array}{l}\text { White coating asphalt reduces temperature by about } 25 \text { and } 33^{\circ} \mathrm{F} \\
\text { compared to asphalt and concrete pavements }\end{array}$ \\
\hline [170] & $\begin{array}{l}\text { Apply reflective roofs on two small } \\
\text { non-residential buildings }\end{array}$ & $\begin{array}{l}0.26 \text { and } 0.72 \text { before and after the } \\
\text { installation }\end{array}$ & $\begin{array}{l}\text { Average reduction of about } 10{ }^{\circ} \mathrm{C} \text { in daytime during the summer of } \\
2000\end{array}$ \\
\hline [171] & Monitor cool roofs in six California & Increase ranges from 0.33 to 0.62 & Daily peak surface temperature reduces by $33-42^{\circ} \mathrm{C}$ \\
\hline
\end{tabular}




\begin{tabular}{|c|c|c|c|}
\hline & buildings at three different sites & & \\
\hline [172] & $\begin{array}{l}\text { Apply reflective roofs on a residential } \\
\text { building in Australia }\end{array}$ & About 0.2 after application & Reduction of about $20^{\circ} \mathrm{C}$ during the September of 2005 \\
\hline [173] & $\begin{array}{l}\text { Apply reflective roofs on the east half of a } \\
\text { roof in Phoenix }\end{array}$ & $\begin{array}{l}0.3 \text { and } 0.72 \text { before and after the } \\
\text { installation }\end{array}$ & Reduction of 8-14 ${ }^{\circ} \mathrm{C}$ in daytime during August 20-22, 2008 \\
\hline
\end{tabular}


Table 3. Summary of impacts on air temperature by reflective materials from existing studies

\begin{tabular}{|c|c|c|c|}
\hline Reference & Methodology & Albedo increase & Temperature change \\
\hline [21] & MM5 v3.6.1 and MRF & $\begin{array}{l}0.45 \text { and } 0.67 \text { on roof over Athens for } \\
\text { moderate and extreme cases }\end{array}$ & $\begin{array}{l}\text { Reduction of up to } 1.5 \text { and } 2.2{ }^{\circ} \mathrm{C} \text { at } 2 \mathrm{~m} \text { height in moderate and extreme } \\
\text { cases on } 15 \text { August, } 2005\end{array}$ \\
\hline$[22]$ & CSUMM & $\begin{array}{l}0.35,0.5 \text { and } 0.25 \text { on sloped roof, flat } \\
\text { roof and road in Los Angeles Basin }\end{array}$ & Reduction of up to $3{ }^{\circ} \mathrm{C}$ in summertime \\
\hline$[46]$ & WRF v3.2.1 & $\begin{array}{l}\text { Increased to } 0.88 \text { under maximum } \\
\text { expansion scenario in Sun Corridor }\end{array}$ & $\begin{array}{l}\text { Regional average } 2 \mathrm{~m} \text { air temperature reduces by } 0.83,0.77 \text { and } 0.7^{\circ} \mathrm{C} \text { in } \\
\text { spring, summer and fall, respectively }\end{array}$ \\
\hline$[47]$ & WRF v3.2.1 & $\begin{array}{l}\text { Cool roofs in urban areas over the U.S. } \\
\text { under urban expansion scenario }\end{array}$ & $\begin{array}{l}\text { Average } 2 \mathrm{~m} \text { air temperature reduces in all investigated urban areas, up to } \\
2{ }^{\circ} \mathrm{C} \text { in Mid-Atlantic and California }\end{array}$ \\
\hline [48] & uMM5 and CAMx & $\begin{array}{l}0.1,0.25 \text { and } 0.08 \text { on roof, wall and } \\
\text { paved surfaces in urban areas }\end{array}$ & $\begin{array}{l}\text { Reduction of up to } 3{ }^{\circ} \mathrm{C} \text { in daytime during the summer in Sacramento, } \\
\text { California }\end{array}$ \\
\hline [54] & CFD and TRNSYS & 0.12 in an urban park in Athens & Reduction of up to $1.9^{\circ} \mathrm{C}$ during a typical summer day \\
\hline$[58]$ & CFD simulation & 0.51 on pavement surface & $\begin{array}{l}\text { Reduction of } 6 \text { and } 1{ }^{\circ} \mathrm{C} \text { in maximum and minimum air temperature at } \\
1.5 \mathrm{~m} \text { height during the summer }\end{array}$ \\
\hline [59] & WRF & $\begin{array}{l}\text { Urban albedo is doubled and tripled in } \\
\text { Atlanta }\end{array}$ & $\begin{array}{l}\text { Negligible reduction when albedo doubled, reduction of about } 2.5{ }^{\circ} \mathrm{C} \text { in } \\
2 \mathrm{~m} \text { air temperature at } 2 \mathrm{PM}\end{array}$ \\
\hline$[60]$ & TUF-IOBES & 0.4 on ground & $\begin{array}{l}\text { Reduction of } 0.4{ }^{\circ} \mathrm{C} \text { at } 2 \mathrm{PM} \text { in canopy with aspect ratio of } 0.37 \text {, } \\
\text { reduction decreases with aspect ratio }\end{array}$ \\
\hline$[61]$ & $\begin{array}{l}\text { Install a cool roof on a } 700 \mathrm{~m}^{2} \\
\text { roof in Sicily }\end{array}$ & 0.86 after installation & $\begin{array}{l}\text { Average indoor air temperature reduces by } 2.9 \text { and } 3.1^{\circ} \mathrm{C} \text { in two studied } \\
\text { rooms. Change of outdoor air temperature is insignificant }\end{array}$ \\
\hline$[62]$ & ENVI-Met & 0.5 on ground in Malaysia & $\begin{array}{l}\text { Reduction of up to } 0.2^{\circ} \mathrm{C} \text { at } 3 \mathrm{~m} \text { height under high density trees } \\
\text { condition on February 28, } 2009\end{array}$ \\
\hline$[63]$ & GATOR-GCMOM & 0.53 on roof worldwide & $\begin{array}{l}\text { Population-weighted air temperature reduces by about } 0.02{ }^{\circ} \mathrm{C} \text {, global air } \\
\text { temperature is increased by about } 0.07{ }^{\circ} \mathrm{C}\end{array}$ \\
\hline$[65]$ & CSCRC and CFD & Not available & Reduction of about $0.1{ }^{\circ} \mathrm{C}$ by reflective pavement in Tokyo \\
\hline$[98]$ & TRNSYS & $\begin{array}{l}0.65 \text { on roof over } 27 \text { cities around the } \\
\text { world }\end{array}$ & $\begin{array}{l}\text { Maximum indoor air temperature in non-air-conditioned residential } \\
\text { buildings reduces by } 1.2-3.3{ }^{\circ} \mathrm{C}\end{array}$ \\
\hline [99] & CLMU, CLM3.5, and & 0.58 on roof & Average urban daily maximum and minimum air temperature reduce by \\
\hline
\end{tabular}




\begin{tabular}{|c|c|c|c|}
\hline & CAM3.5 & & 0.6 and $0.3^{\circ} \mathrm{C}$, respectively \\
\hline [100] & TUF3D & $\begin{array}{l}\text { Albedo is } 0.08,0.18 \text { and } 0.35 \text { on } \mathrm{AT} \text {, } \\
\text { asphalt and concrete }\end{array}$ & $\begin{array}{l}\text { Daily maximum air temperature is the lowest on concrete and the highes } \\
\text { on AT surface }\end{array}$ \\
\hline [120] & EnergyPlus $^{\mathrm{TM}}$ & 0.55 on roof & Reduction of up to about $2{ }^{\circ} \mathrm{C}$ in non-insulated house in July \\
\hline [138] & CSUMM and UAM & $\begin{array}{l}0.15 \text { and } 0.30 \text { in moderate and extreme } \\
\text { cases }\end{array}$ & $\begin{array}{l}\text { Reduction of } 2 \text { and } 4.5^{\circ} \mathrm{C} \text { in moderate and extreme cases in central } \\
\text { California's South Coast Air Basin }\end{array}$ \\
\hline [139] & uMM5 and CAMx & 0.2 to 0.4 on various urban surfaces & $\begin{array}{l}2 \mathrm{~m} \text { air temperature reduces by up to } 2{ }^{\circ} \mathrm{C}, 1.5^{\circ} \mathrm{C} \text { and } 1.0^{\circ} \mathrm{C} \text { in Los } \\
\text { Angeles, San Jose, and Sacramento }\end{array}$ \\
\hline [141] & CSUMM & $\begin{array}{l}0.35 \text { and } 0.25 \text { on roofs and pavements in } \\
\text { Los Angeles }\end{array}$ & Population-averaged temperature reduces by up to $1.5^{\circ} \mathrm{C}$ at about $2 \mathrm{PM}$ \\
\hline$[142]$ & CSUMM & 0.15 over downtown Los Angeles & Reduction of up to $1.5^{\circ} \mathrm{C}$ in summertime \\
\hline [160] & $\begin{array}{l}\text { Monitor white and black roofs } \\
\text { in Austin }\end{array}$ & Not available & Reduction of $5{ }^{\circ} \mathrm{C}$ in indoor air temperature on a moderately warm day \\
\hline$[166]$ & TRNSYS & 0.69 on a $410 \mathrm{~m}^{2}$ school roof in Athens & $\begin{array}{l}\text { Indoor air temperature reduces by } 1.5-2{ }^{\circ} \mathrm{C} \text { during summer and by } 0.5^{\circ} \mathrm{C} \\
\text { during winter }\end{array}$ \\
\hline [174] & MM5 & 0.1 in Philadelphia & Average reduction of 0.3 to $0.5{ }^{\circ} \mathrm{C}$ in daytime \\
\hline [175] & MM5 and SEBM & $\begin{array}{l}\text { Reflective roofs and pavements over the } \\
\text { entire New York City }\end{array}$ & $\begin{array}{l}\text { Average near-surface air temperature reduces by } 1.3{ }^{\circ} \mathrm{F} \text {, average } \\
\text { reduction at } 3 \mathrm{PM} \text { is } 2.2{ }^{\circ} \mathrm{F} \text { during the summer of } 2002\end{array}$ \\
\hline
\end{tabular}


Table 4. Summary of observed UHI intensities of major cities in the world

\begin{tabular}{lllll}
\hline Reference & City & Time & Type & Intensity $\left({ }^{\circ} \mathrm{C}\right)$ \\
\hline$[2]$ & Beijing & 1030 LST, Aug, 2001 & Surface temperature & 10 \\
\hline$[73]$ & Beijing & 1000 LST, Aug, 2005 & Air temperature & 0.05 \\
\hline$[74]$ & Houston & 0200 - 0530 LST, 1985 - 1987 & Surface temperature & 2.35 \\
\hline & Houston & 0200 - 0530 LST, 1999 - 2001 & Surface temperature & 3.10 \\
\hline$[75]$ & London & Aug, 2000 & Mean air temperature & 1.0 \\
\hline$[2]$ & Manila & 1030 am, Nov, 2001 & Surface temperature & 7 \\
\hline$[76]$ & Melbourne & 0600 LST, 1972 - 1991 & Air temperature & 1.13 \\
\hline$[77]$ & Mexico city & 1100 - 1500 LST, Aug - Sep, 1994 & Air temperature & $3-5$ \\
\hline$[78]$ & New York & 1900 - 2000 & Mean air temperature & $2-3$ \\
\hline$[79]$ & New York & Summer, 1997 - 1998 & Mean air temperature & 4 \\
\hline$[80]$ & Paris & 01 - 12 Jun, 2006 & Mean air temperature & 2.56 \\
\hline$[81]$ & Phoenix & 03 - 12 Apr, 2002 & Mean air temperature & $9.4-12.9$ \\
\hline$[82]$ & Phoenix & Jun, 1990 - 2004 & Mean minimum air temperature & $2-4$ \\
\hline$[2]$ & Seoul & 1030 LST, Aug, 2001 & Surface temperature & 8 \\
\hline$[70]$ & Seoul & 1500 LST, Mar 2001 - Feb 2002 & Air temperature & 0.6 \\
\hline$[2]$ & Shanghai & 1030 LST, Aug, 2001 & Surface temperature & 7 \\
\hline$[2]$ & Shanghai & 1030 LST, Jan, 2002 & Surface temperature & 3 \\
\hline$[83]$ & Singapore & 2100 LST, Mar 2003 - Mar 2004 & Air temperature & 3.8 \\
\hline$[84]$ & Tokyo & 0300 - 0500 LST, 14 Mar, 1992 & Air temperature & 8.0 \\
\hline$[2]$ & Tokyo & 1030 LST, Aug, 2001 & Surface temperature & 12 \\
\hline$[2]$ & Tokyo & 1030 LST, Jan, 2002 & Surface temperature & 4 \\
\hline & & & & \\
\hline
\end{tabular}


Table 5. Summary of impacts on energy consumption by reflective materials from existing studies

\begin{tabular}{|c|c|c|c|}
\hline Reference & Methodology & Albedo increase & Energy consumption \\
\hline [22] & $\begin{array}{l}\text { Monitor white roofs on houses in } \\
\text { Sacramento and Florida during the } \\
\text { summers of } 1991 \text { and } 1992\end{array}$ & 0.55 & $\begin{array}{l}40 \% \text { reduction in seasonal cooling energy in Sacramento. } 40-50 \% \\
\text { and } 35 \% \text { reduction in energy consumption and peak power demand } \\
\text { for school bungalows }\end{array}$ \\
\hline [47] & WRF v3.2.1 & $\begin{array}{l}\text { Cool roofs over the U.S. under } \\
\text { urban expansion scenario }\end{array}$ & $\begin{array}{l}\text { Winter heating penalty can reduce, roll back or even exceed cooling } \\
\text { energy savings in summers }\end{array}$ \\
\hline [60] & TUF-IOBES & 0.4 on ground & $\begin{array}{l}\text { Annual cooling load is increased by up to } 11 \% \text { in nonresidential } \\
\text { office buildings ( } 47 \% \text { window to wall ratio) in Phoenix }\end{array}$ \\
\hline [95] & DOE2 model & $\begin{array}{l}0.3 \text { and } 0.45 \text { for residential and } \\
\text { commercial building roofs }\end{array}$ & $\begin{array}{l}\text { Total annual electricity savings for } 11 \text { metropolitan areas about } 2.6 \\
\text { TWh, peak electricity demand savings about } 1.7 \mathrm{GW}\end{array}$ \\
\hline [96] & DOE2.1-E model & $\begin{array}{l}0.3 \text { on roof for three building } \\
\text { types with various characteristics }\end{array}$ & $\begin{array}{l}\text { Annual electricity savings } 40-1000 \mathrm{kWh} / 1000 \mathrm{ft}^{2} \text { in climate with } \\
\text { more than } 1000 \text { cooling-degree-days over } 240 \text { locations in the U.S. }\end{array}$ \\
\hline [97] & DOE2.1-E model & $\begin{array}{l}0.35 \text { on roof over four types of } \\
\text { commercial buildings }\end{array}$ & $\begin{array}{l}\text { Annual cooling energy saving } 3.30-7.69 \mathrm{kWh} / \mathrm{m}^{2} \text {, heating penalty } \\
0.003-0.065 \text { therm } / \mathrm{m}^{2} \text { in } 236 \text { cities across the U.S. }\end{array}$ \\
\hline [98] & TRNSYS & $\begin{array}{l}0.65 \text { on roof over } 27 \text { cities around } \\
\text { the world }\end{array}$ & $\begin{array}{l}\text { Cooling loads reduce by } 18-93 \% \text { and peak cooling demands in } \\
\text { air-conditioning building reduce by } 11-27 \% \text {. }\end{array}$ \\
\hline [99] & CLMU, CLM3.5, and CAM3.5 & 0.58 on roof & $\begin{array}{l}\text { With respect to the global annual average, heating fluxes increase } \\
\text { more than air conditioning fluxes decrease }\end{array}$ \\
\hline [100] & TUF3D & $\begin{array}{l}\text { Albedo is } 0.08,0.18 \text { and } 0.35 \text { on } \\
\text { AT, asphalt and concrete }\end{array}$ & $\begin{array}{l}\text { Radiative energy from ground to wall increases with albedo of the } \\
\text { ground materials }\end{array}$ \\
\hline [120] & EnergyPlus $^{\mathrm{TM}}$ & 0.55 on roof & Annual energy savings vary from $-13.7 \%$ to $41.7 \%$ \\
\hline [161] & ESP-r & 0.4 on roof & $0.4 \%$ saving in annual building need for heating and cooling \\
\hline [166] & TRNSYS & $\begin{array}{l}0.69 \text { on a } 410 \mathrm{~m}^{2} \text { school roof in } \\
\text { Athens }\end{array}$ & $\begin{array}{l}\text { Annual cool loading reduces by } 40 \% \text { and heating penalty is } \\
\text { increased by about } 10 \%\end{array}$ \\
\hline [170] & $\begin{array}{l}\text { Monitor white roofs on two small } \\
\text { buildings in Nevada }\end{array}$ & 0.46 & $\begin{array}{l}\text { Monitored electricity saving about } 0.5 \mathrm{kWh} / \mathrm{d} \text { during summer, } \\
\text { estimated annual saving about } 100-125 \mathrm{kWh} / \mathrm{yr} \text { in } 2000\end{array}$ \\
\hline [171] & $\begin{array}{l}\text { Monitor cool roofs in six California } \\
\text { buildings at three different sites }\end{array}$ & 0.33 to 0.62 & $\begin{array}{l}\text { Energy savings } 42-81 \mathrm{Wh} / \mathrm{m}^{2} / \mathrm{d} \text { during summer, average peak } \\
\text { demand savings } 2.6-6.6 \mathrm{Wh} / \mathrm{m}^{2} \text { for hours from noon to } 5 \mathrm{pm} \text {, annual }\end{array}$ \\
\hline
\end{tabular}




\begin{tabular}{|c|c|c|c|}
\hline & during the summer of 2002 & & energy savings $3-15 \mathrm{kWh} / \mathrm{m}^{2} / \mathrm{yr}$ \\
\hline [173] & EnergyPlus $^{\mathrm{TM}}$ & $\begin{array}{l}0.42 \text { on a commercial building } \\
\text { roof in Phoenix }\end{array}$ & $\begin{array}{l}\text { Total monthly electricity consumption reduces by } 1.3-1.9 \% \text { and } \\
2.6-3.8 \% \text { for } 50 \% \text { and } 100 \% \text { cool roof replacement in August }\end{array}$ \\
\hline [176] & $\begin{array}{l}\text { Monitor cool roofs on one house and } \\
\text { two school bungalows in Sacramento } \\
\text { during summers of } 1991 \text { and } 1992\end{array}$ & 0.55 & $\begin{array}{l}2.2 \mathrm{kWh} / \mathrm{d} \text { saving in electricity for the house. } 80 \% \text { and } 35 \% \\
\text { reduction in seasonal cooling energy for house and bungalows, } \\
\text { respectively. } 0.6 \mathrm{~kW} \text { reduction in peak cooling power }\end{array}$ \\
\hline [177] & $\begin{array}{l}\text { Monitor reflective roofs on } 9 \\
\text { residential buildings from } 1991 \text { to } \\
1994 \text { in Florida }\end{array}$ & 0.3 to 0.53 & $\begin{array}{l}\text { 2-3\% reduction in air conditioning energy among the buildings, } 7.4 \\
\text { kWh/d (19\%) average drop in space cooling energy. Peak electricity } \\
\text { demand reduces by 201-988 W (12-38\%) }\end{array}$ \\
\hline [178] & DOE2.1-E model & $\begin{array}{l}0.3 \text { and } 0.4 \text { for residential and } \\
\text { commercial building roofs }\end{array}$ & $\begin{array}{l}\text { Annual electricity savings about } 30 \mathrm{GWh} \text {, peak power avoidance } \\
\text { about } 50 \mathrm{MW}\end{array}$ \\
\hline [179] & STAR & 0.15 on roof & $\begin{array}{l}\text { Annual cool loading reduces by } 37.5 \% \text { and heating penalty is } \\
\text { increased by about } 8.09 \% \text { in Climate Zone } 12 \text { (Sacramento) }\end{array}$ \\
\hline [180] & $\begin{array}{l}\text { Apply cool roof on five non-air- } \\
\text { conditioned buildings across Europe }\end{array}$ & Not available & Energy savings range from 10 to $40 \%$ \\
\hline
\end{tabular}

